Iranian Quarterly Journal of Breast Disease 2018; 11(4):65.

\title{
Tumor Classification in Breast Magnetic Resonance Images (MRI) Using the Level Set-Based Segmentation Method and Gabor-Haralik Feature
}

Pashoutan S :School of Electrical Engineering, Iran University of Science and Technology, Tehran, Iran Ayatollahi F :School of Electrical Engineering, Iran University of Science and Technology, Tehran, Iran Baradaran Shokouhi S: School of Electrical Engineering, Iran University of Science and Technology, Tehran, Iran

Corresponding Author: Soheil Pashoutan, Soheil.Pashootan@gmail.com

\begin{abstract}
Introduction: Breast cancer can be considered as the most common cancer among women in the world. Hence, finding appropriate diagnosis methods is a critical and sensitive challenge in the health of the human community. Various methods have been proposed for breast screening in women, and one of the safest methods is magnetic resonance imaging. Tumors do not have morphological features of their own. Therefore, differentiating between benign and malignant lesions is normally very time-consuming and difficult. In this study, a computer-aided autodiagnosis system is developed for diagnosis and classification of axial magnetic resonance images of the breast in two classes of benign and malignant.
\end{abstract}

Methods: Initially, suspected parts of the lesion were separated as a rectangular box around the lesion by an experienced radiologist. Then, we used, for the first time, a level set-based algorithm to precisely separate the lesion considering the unevenness of the images and to remove false positive regions using morphological operations and removing veins. In the next stage, four groups of features expressing particular states of the lesion structure are extracted from the separated parts of the lesions. These four groups are textural, kinetic, frequency, and morphological features. Here a new group of features called the Gabor-Haralik features, which present a particular efficiency, was extracted for each lesion. Finally, MLP classification was used to classify the lesions.

Results: The proposed method was tested on 46 lesions. By utilizing Gabor-Haralik features, we achieved mean sensitivity, specificity, accuracy, and F-measure of 95.41, 90.70, 92.76, and $92.19 \%$, respectively.

Conclusion: The performance measures indicate the efficiency of the proposed diagnosis system for classification of benign and malignant breast lesions in magnetic resonance imaging.

Keywords: Diagnosis System, Breast Segmentation, Feature Extraction, Classification 


\title{
طبقهبندى ضايعات بستان در تصاوير رزونانس مغناطيسى با استفاده از روش جداسازى مبتنى

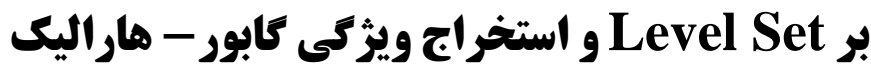

\author{
سهيل هشوتن": كروه مهندسى برق الكترونيك، دانشكده برق، دانشكاه علم و صنعت ايران، تهران، ايران

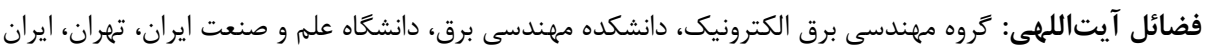

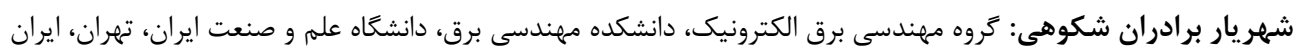

مقدمه: سرطان يستان را مىتوان شايعترين سرطان در ميان زنان جهان ناميد. از اين رو يافتن راههايى براى تشخيص و درمان

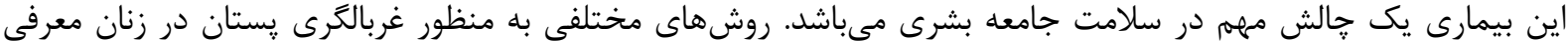

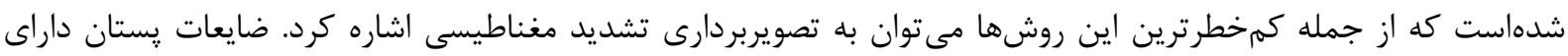

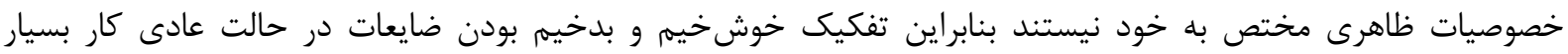
زمانبر و دشوارى مىباشد. در اين يزوهش يك سيستم آسيبشناسى خودكار با كمك كاميِيوتر براى تشخيص و دستهبندى

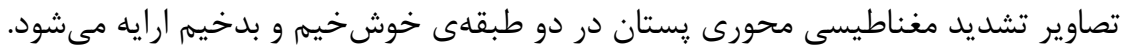

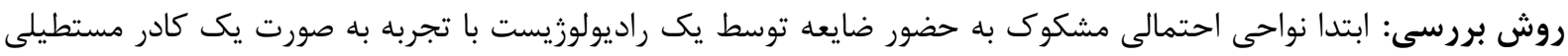

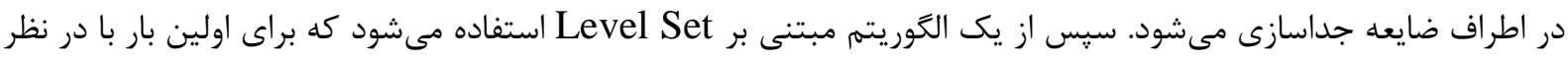

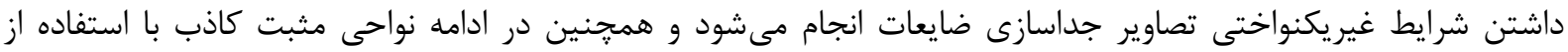

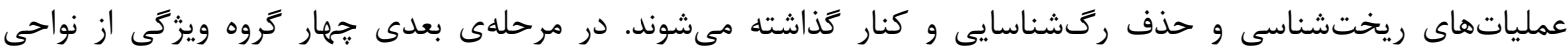

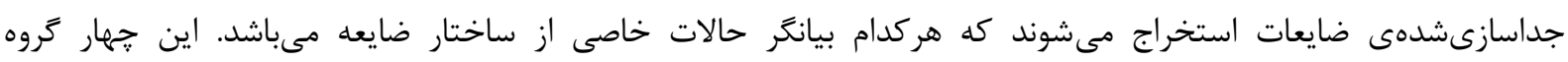

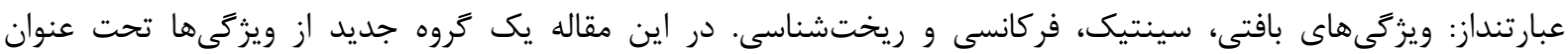

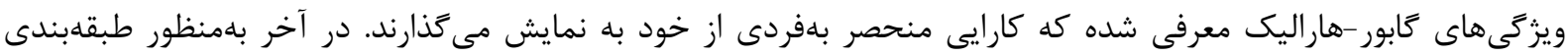

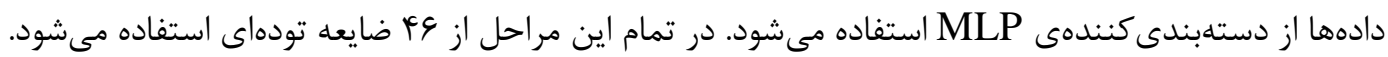

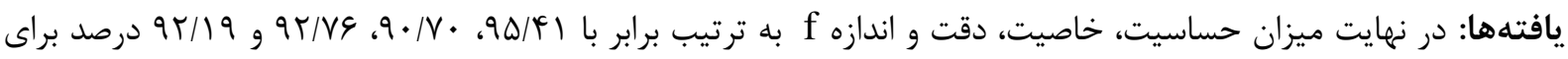

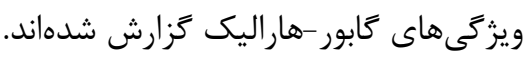

نتيجهَّيرى: اين مقادير كارايى مناسب سيستم آسيبشناسى بيشنهادى در دستهبندى ضايعات تودهاى خوشخيم و و بدخيم

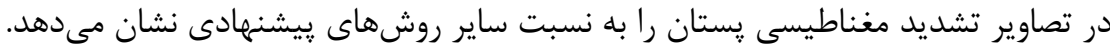

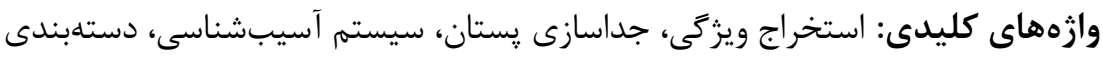


ممكن است نتواند باعث تشخيص درست شود. بسيارى از

متخصصين و سازمآنهاى نظارتى تنها اين روش را براى زنهاى مسن توصيه مى كنند (9). طبق توصيههايى كه در

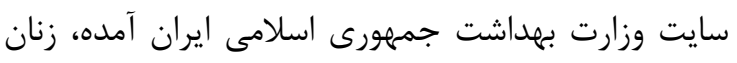

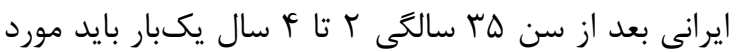

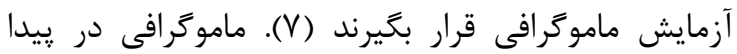

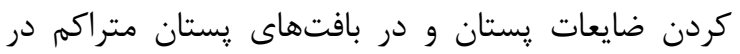

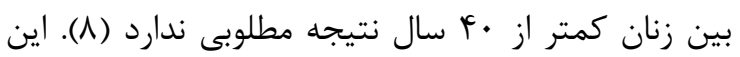
اتفاق به اين دليل مىافتد كه ماموگرافى در تشخيص سرطانهاى ״ستان تهاجمى در بافتهاى پِّتان متراكم

ضعيف است (9).

براى تشخيص سرطانهايى كه در ماموكرافى قابل

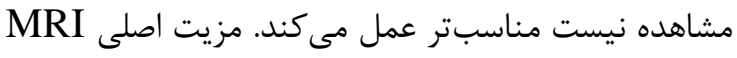
קستان، در توان تشخيص درست ضايعات بدخيم است.

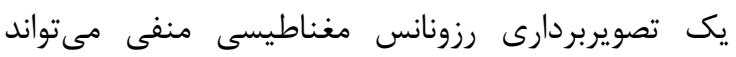
وجود سرطان را با درجهى بالايى از اطمينان نمايان كند و ودئ

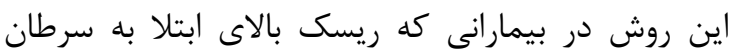

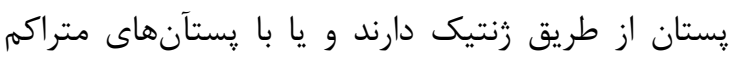

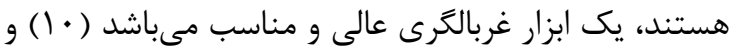

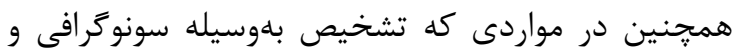

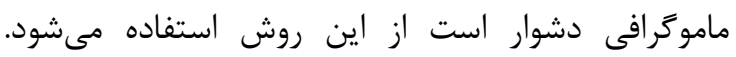

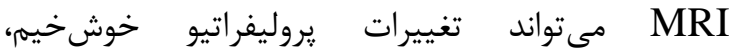
فيبرودنوماها و ديكر يافتههاى خوشخيم را در يكى نتخاه تشخيص دهد و در نتيجه نياز به هزينه و بيويسى هاى غيرضرورى را از بين مىبرد. علىرغم كمكهاى شايانى كه نه در تصويربردارى MR وجود دارد، اين روش داراى معايبى

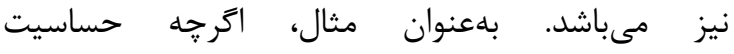

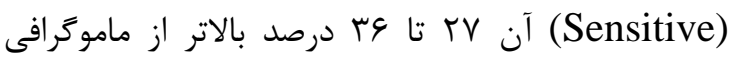
است اما خاصيت (Specific) آن به نسبت كمتر است

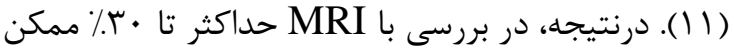
است نتايج مثبت كاذب (False Positive) داشته باشيم كه اين امر موجب افزايش هزينههاى مالى و روانى

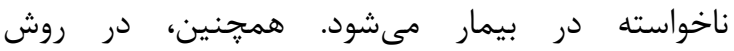

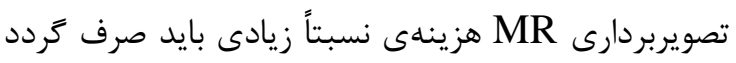

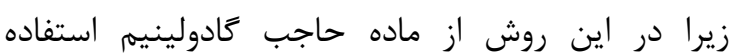
مىشود. با تمام اين تفاسير، استفاده از روش تصويربردارى إن إن

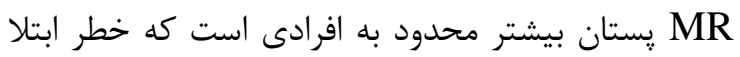

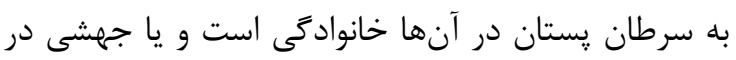
زنهاى BCRA1/2 در آنها وجود دارد (ז آ). همجنين
سرطان קِتان اصلىترين عامل مرى و مير ناشى از

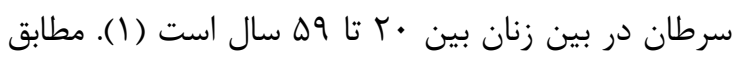

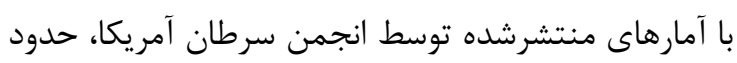
• مورد سرطان (

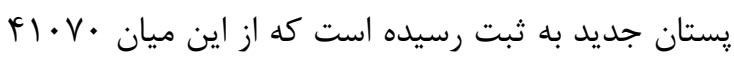

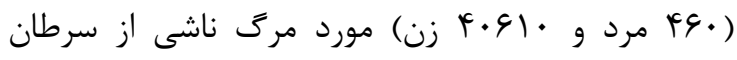

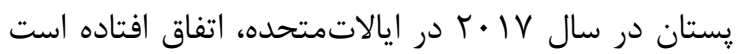

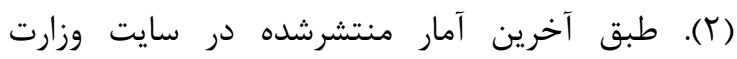

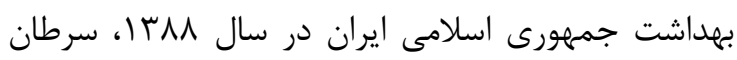

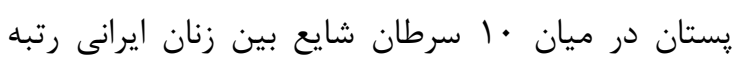

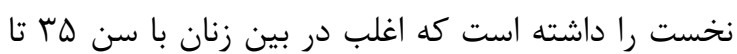

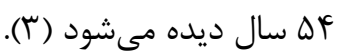

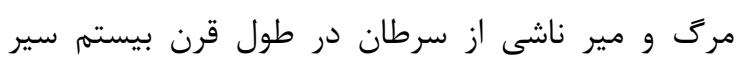

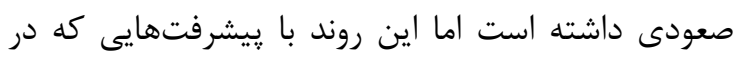
تشخيص زودهنگام سرطان صورت كرفته است، از سال

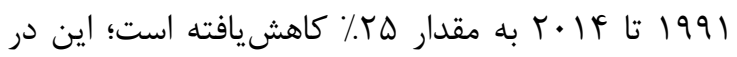

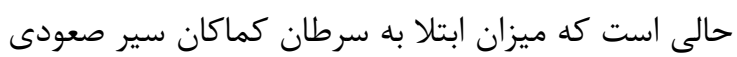

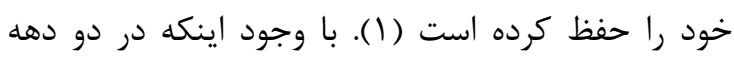

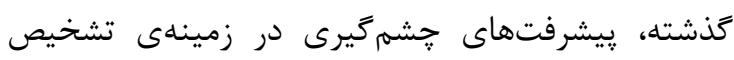

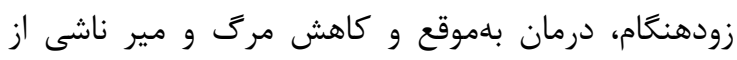

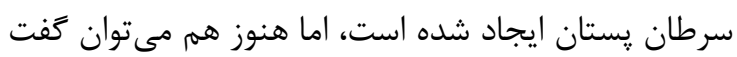

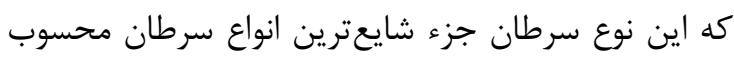

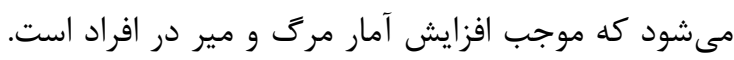

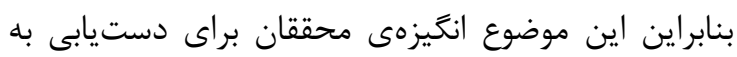

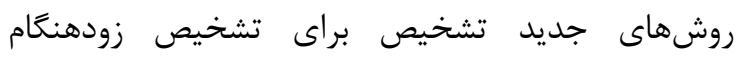

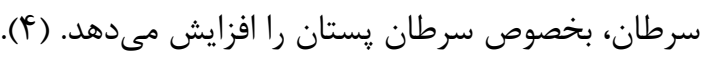

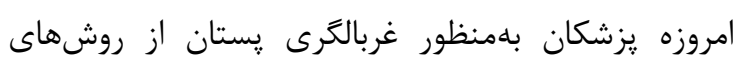

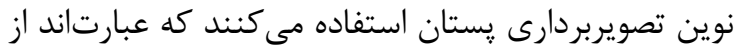

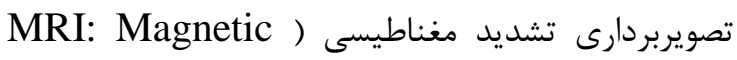
Resonance Imaging تصويربردارى مولكولى از پِتان، اسكن PET، ترموكرافى،

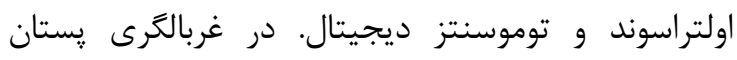

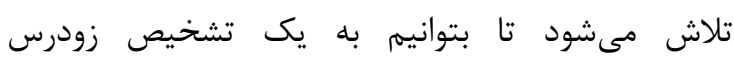

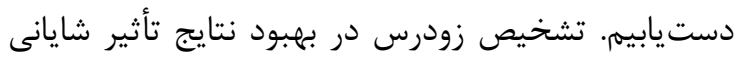

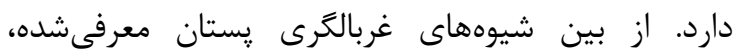

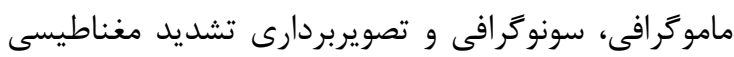

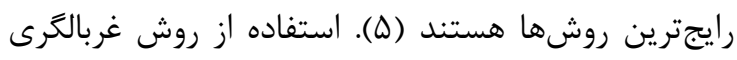
با استفاده از ماموكرافى بسيار بحث برانگيز است؛ زيرا 
علاوه بر بافت يستان نواحى اضافى ديگرى مانند قلب نيز

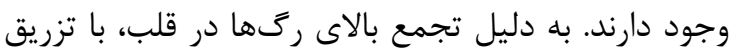
ماده حاجب تقابل آن نيز بهبوديافته و شدت دادئ سيكنال

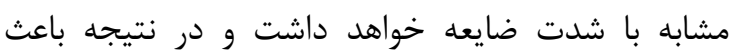

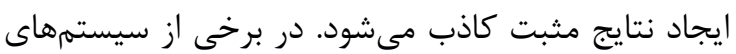

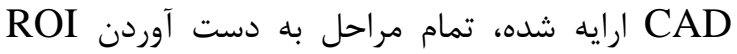

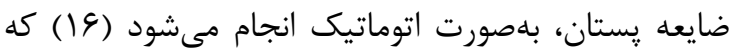

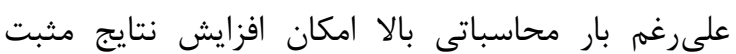

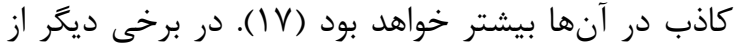

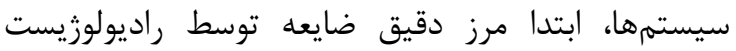

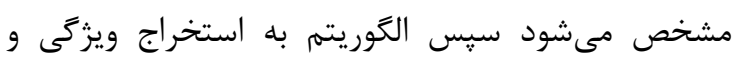

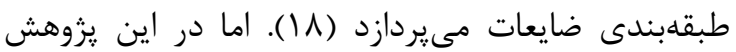
ابتدا ROI اطراف ضايعه توسط راديولوزيست جداسازى

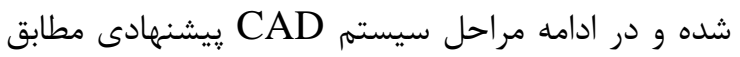
با شكل 1 انجام مىشود. ازآنجايى كه شكل ظاهرى ضايعه

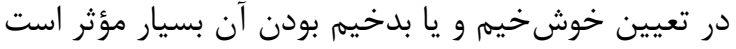
(9)، جداسازى دقيق لبههاى ضايعات از اهميت بالايى

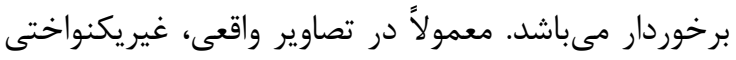
شدت سيكنال وجود دارند كه اين امر يك جالش قابلتوجه در جداسازى تصاوير است

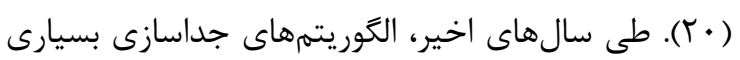
معرفى شدهاند كه غالباً بر يكنواختى شدت سيخنال تأكيد الكرايد دارند و مشخصاً براى تصاويرى با غيريكنواختى شدت

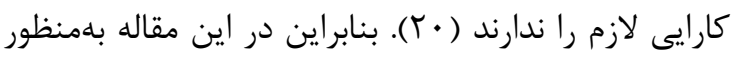
جداسازى ضايعات در ROI Rاى بلهدستآمده توسط راديولوزيست مربوط به تصاوير MR، از يك روش بران مبناى كانتور فعال (Active Contour-based) به نام تصاه، استفادهده است كه بهمنظور جداسازى تصاوير، با در نظر داشتن غيريكنواختى درشدت سيكنال

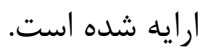

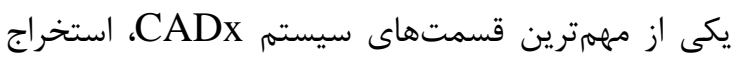
ويزگى مىباشد. در بحث تردازش تصوير و شناسايى الكو

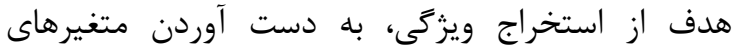

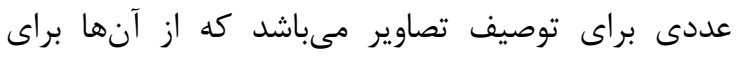

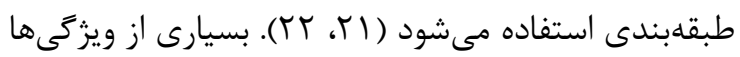
از قبيل ويزگى هاى ريختشناسى، ويزَّىهاى بافتى،

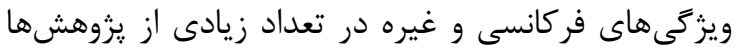

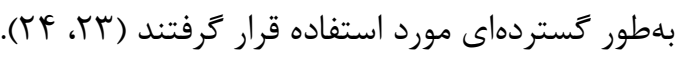

استفاده از تصويربردارى MR اغلب براى بيمارانى كه در بدن آنها از دستگاه ضربانساز يا منقبض كنندهى بافت استفاده مىشود، محدود است. اين روش تصويربردارى إن إن إنان

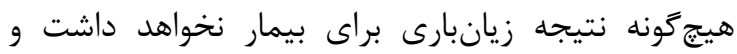
خروجى آن در سه بُعد بهدست مى آيد ولى در ماموكرافي

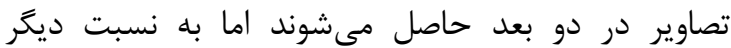
روشها تعداد تصاوير توليد شده در اينجا براى هر بيمار

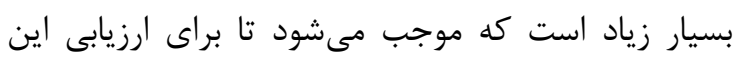
تصاوير زمان زيادى صرف شود (بآ).

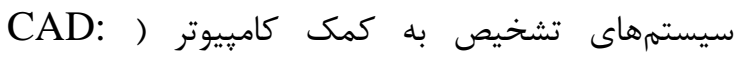
از Computer Aided Diagnosis / Detection مجموعه ابزارهاى خودكار و يا نيمهخودكار تشكيلشدهاند كه بهمنظور كمك به راديولوزيستها براى ارزيابى بهتر

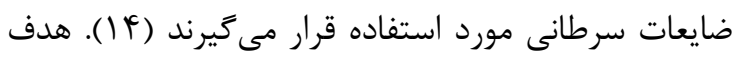
كلى اين يزوهش، ارايه يك سيستم CAD كارآ آمد با دقت

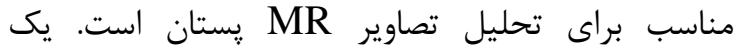
سيستم CAD به دو دسته كلى تقسيمبندى مىشود: CADe: Computer ) بازيابى به كمك كامييوتر (Aided Detection كADx: Computer Aided Diagnosis) كلى اين دودسته هر كدام شامل زير دستههايى هستند كه در شكل 1 نمايش داده شدهاند. زيربخشهاى دئه ديستم دائه CADe

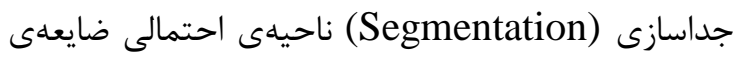

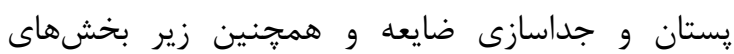
سيستم CADx عبارتاند از استخراج ويزگى و طبقه بندى. كارايى هر بخش بلنوبه خود حايز اهميت است زيرا

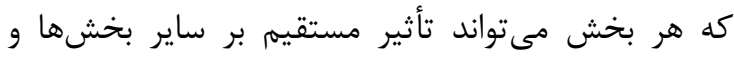

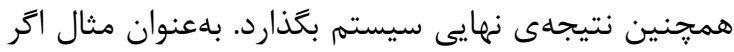
قسمتى از بافت بدخيم يستان بعد از انجام مرحلهى

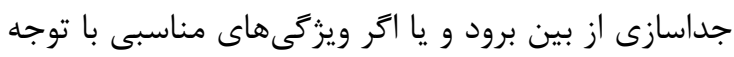
به ماهيت بافت جداسازىشده استخراج نشود اين امر در بر براسئ نتيجه كار تأثير مستقيم دارد و ممكن است موجب ماستاني

تشخيص اشتباه و در نهايت مرك بيمار شود (ها ().

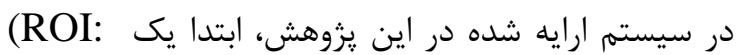
مستطيلى شكل در اطراف Region of Interest)

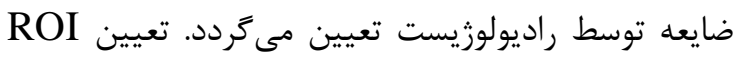

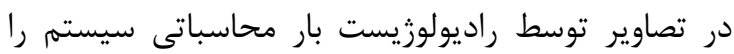
بهشدت كاهش مىدهد. به اين دليل كه در MRI بـ بستان، 


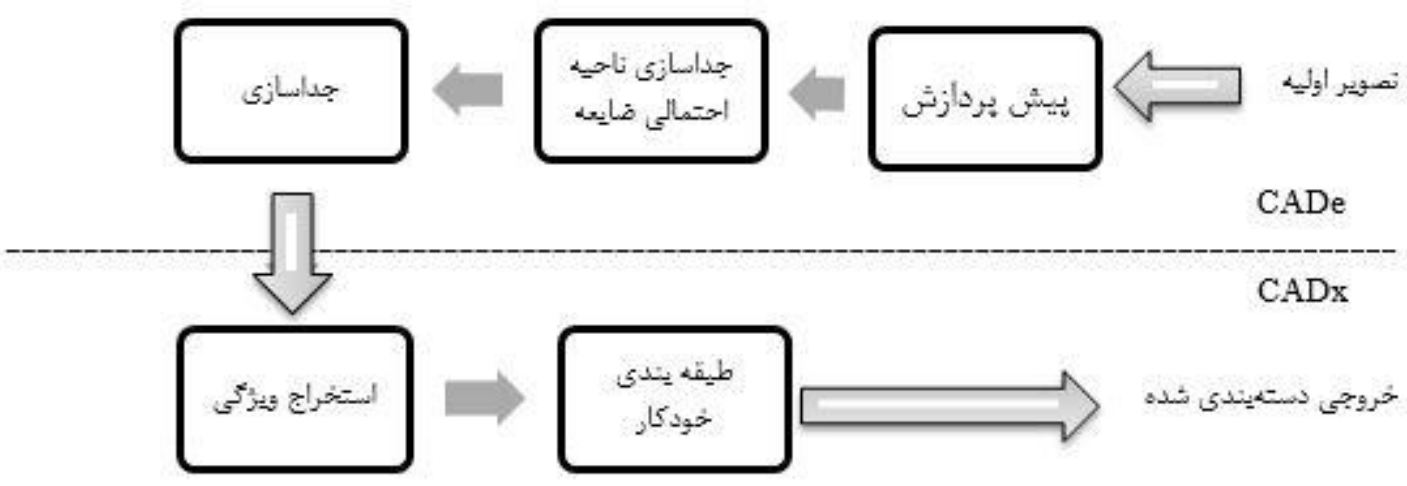

شكل ا: بلوك دياترام سيستم CAD. قسمت بالاى خط رسم شده نشاندهنده اجزاى تشكيل دهنده CADe و قسمت يايين خط رسم

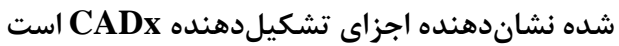

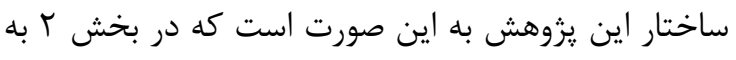

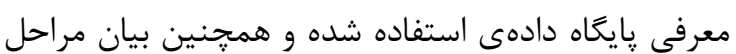
و روش انجام مقاله يرداخته مىشود. مراحل انجام مقاله

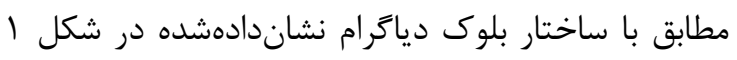
انجام كرفته شده است كه در بخش دو هر بام كدام از بلوكهاى آن به تفصيل مورد بررسى قرار خواهند كرفت. بخش r نيز به بررسى يافتههاى بدست آمده از اين مقاله

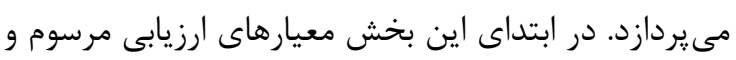

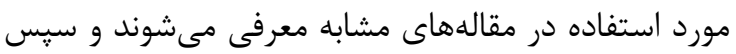
عملكرد سيستم קِيشنهادى در اين مقاله مورد ارزيابى و

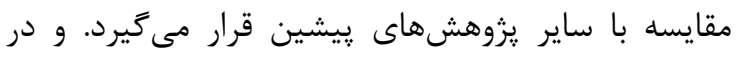
بخش fأ به عنوان آخرين بخش بحث و نتيجه كَيرى كاملى بلى از سيستم پيشنهادى در اين يزوهش ارايه شده است.

\section{مواد و روشها}

سيستم CAD ييشنهادى به دو بخش كلى CADe و

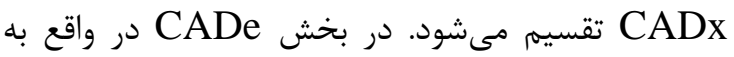

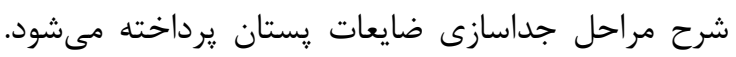
اين بخش شامل زير بخشهاى مختلفى است. ابتدا

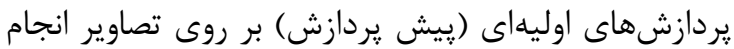

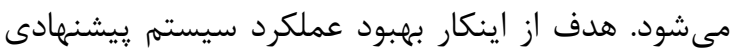

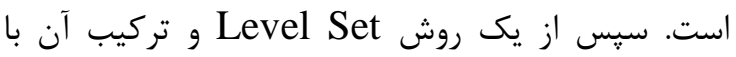
فيلتر تشخيص رى، نواحى ضايعات جداسازى شده و بعد الد

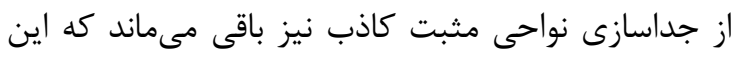

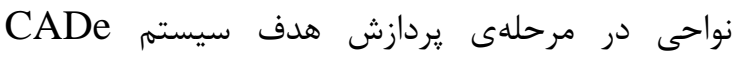
ييشنهادى قرار مى خيرد و اين نواحى نيز به منظور كاهش درد نتايج مثبت كاذب حذف مىشوند. در نتيجه از سيستم CADe
برخى از اين ويزگىها تنها براى ضايعات تصاوير نR

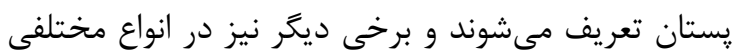

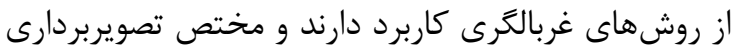
MR در اين مقاله، ما يك سيستم CAD را براى تشخيص توده بدخيم از خوشخيم در MRI پيشنههاد كردهايم كه در سيستم ذكرشده تمركز بر استخراج انواع مختلفى از

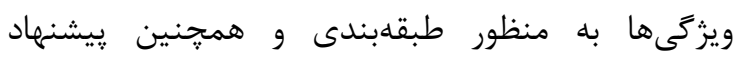
دستهاى از ويزگىهاى جديد و با كيفيت براى افزايش كارايى طبقهبندى ضايعات خوشخيم و بدخيم دارد. ضمن آن

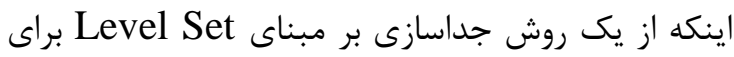
اولين بار در اين يزوهش در تصاوير MR محورى يستان

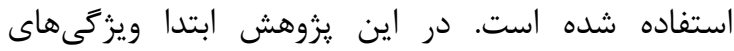
ريختشناسى، بافتى، فركانسى و سينتيك براى مشخص برد

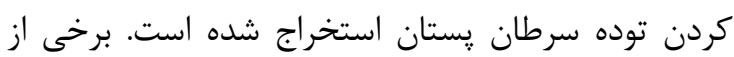

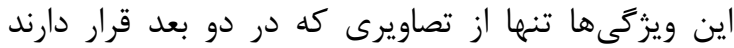

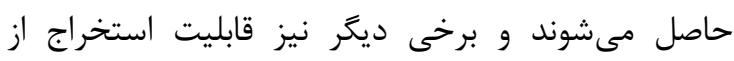

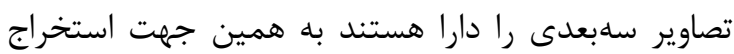
اين ويزگى ها از تصاوير MR به دليل سهبعدى بودن آنها، كارايى بيشترى خواهد داشت. در نهايت ويزكى نهاى

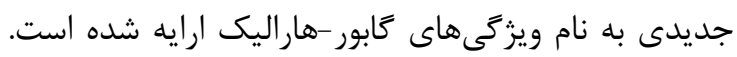

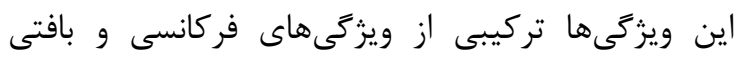

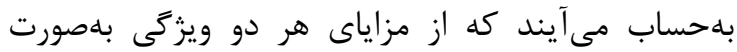

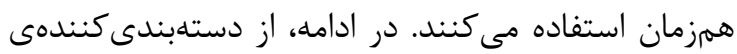

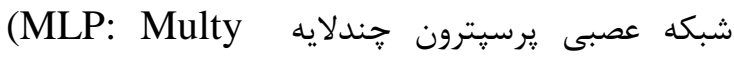
يس انتشار به منظور طبقلبندى Layer perceptron) ضايعات در دو كلاس خوشخيم و بدخيم مورد استفاده

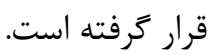


جداسازى ROI احتمالى ضايعه: در اين مرحله از يك

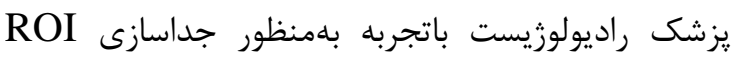

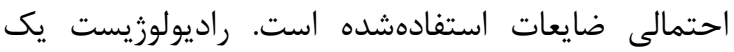
قطعهى (Slice) دوبعدى را از تصاوير MR سهبعدى جدات

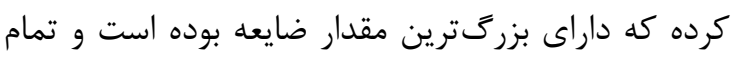
تجزيه و تحليلها تنها برروى آن قطعه دو بعدى انجام

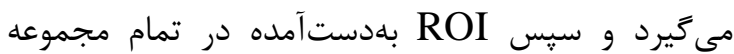
تصاوير مربوط به آن بيمار لحاظ مى شود.

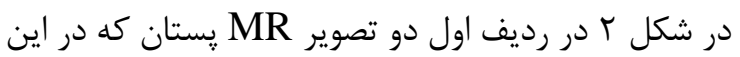

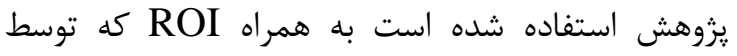

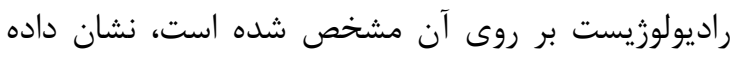

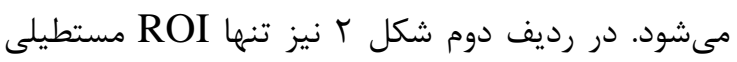
مشخص شده توسط راديولوزيست براى هر يك از تصاوير

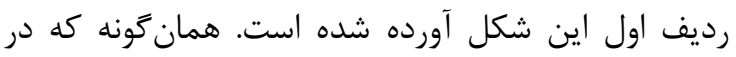

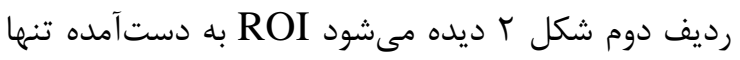
شامل حجم عظيمى از ضايعات مىباشند كه كار را براى تجزيه و تحليل تصاوير سادهتر مى كند. جداسازى ضايعات: تحقيقات اندكى مسئله تشخيص

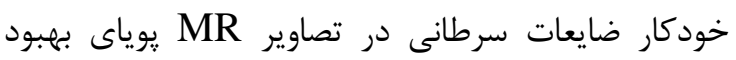
تقابل يافتهى يستان را مورد بررسى قرار دادهاند. برخى از روشهايى كه در مطالعات اخير ارايه شدند، تنها به بيان

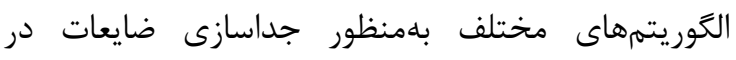
تصاوير مختلف اشاره دارند و تشخيص خودكار ضايعات در

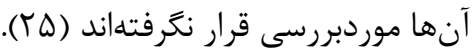

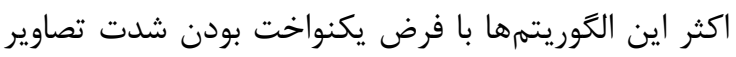

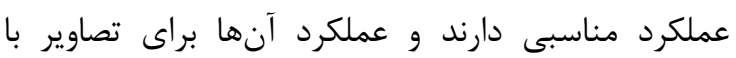

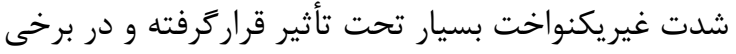
موارد كارايى لازم را ندارند (ع)). غيريكنواختى شدت

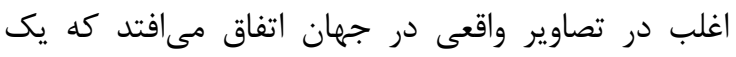
جالش قابل توجه در جداسازى تصاوير است. الكَوريتم يِينههادى در اين مقاله براى اولين بار بر روى

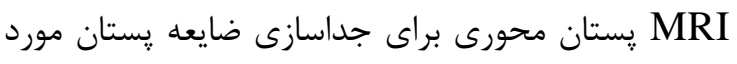

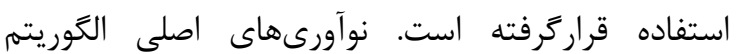

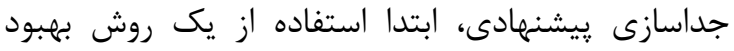

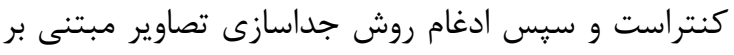

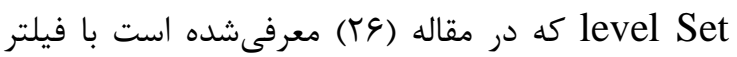

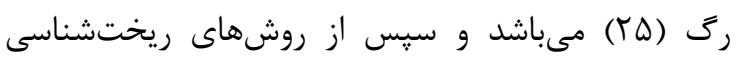
براى كاهش نتايج مثبت كاذب استفاده مىشود.
مراحل CADx استفاده مىشود. در اين مراحل ابتدا

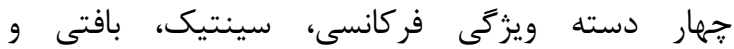
ريختشناسى استخراج مىشوند. هر يك از اين دسته از

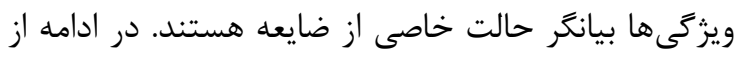

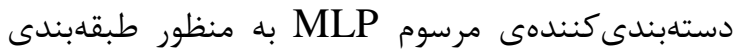
دادهها در دو كلاس خوشخيم و بدخيم استفاده مىشود.

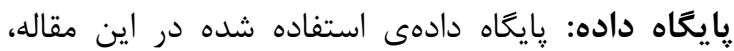

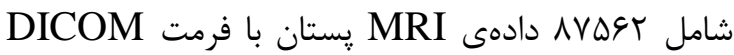
است. اين تعداد داده مربوط به و9 خانم است كه در فاصله

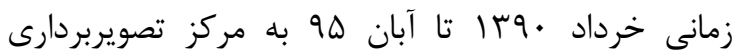

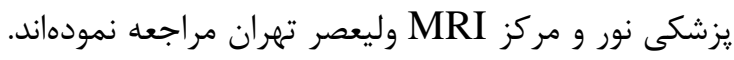

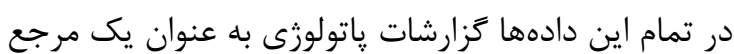

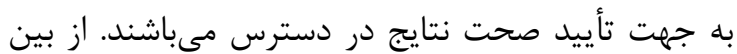
צq خانم بيمار تعداد \&\& مورد داراى ضايعهى تودهاى و

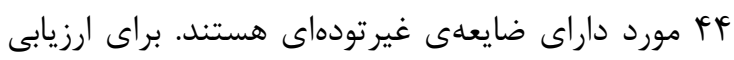

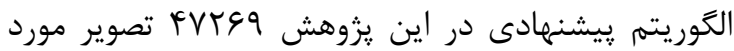

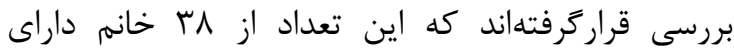

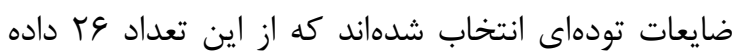

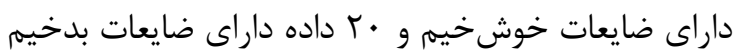

هستند.

در اين يزوهش از بين تمام تصاوير اخذ شده از بيمار،

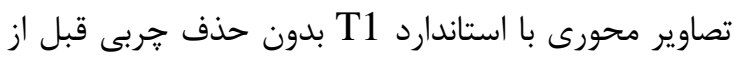

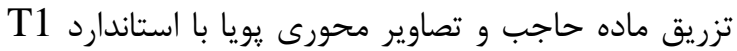
با حذف جربى و بعد از تزريق ماده حاجب مورد استفاده

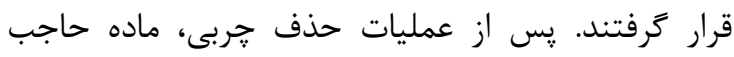
Gd-DTPA به مقدار 1/0 mmol/kg به بيمار تزريقشده و در مركز تصويربردارى يزشكى نور و مركز

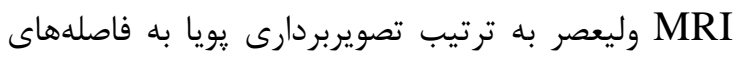

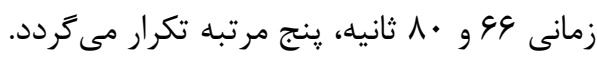
ييش يردازش: وجود نويز سختافزارى، غيريكنواختى شدت سيخنال (ميدان باياس)، حركت بدن بيمار در حين

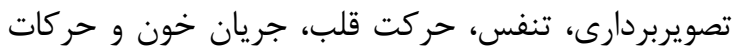
روده از جمله عوامل ايجاد نويز و حركت در تصاوير

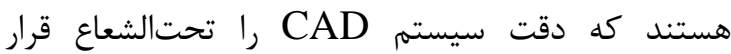

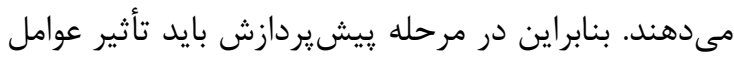

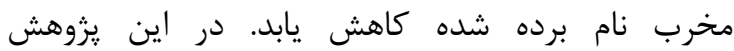
بهوسيلهى انطباق همه تصاوير يس از تزريق ماده حاجب به رشته قبل از تزريق، تصحيح حركت صورت مى كيرد. 

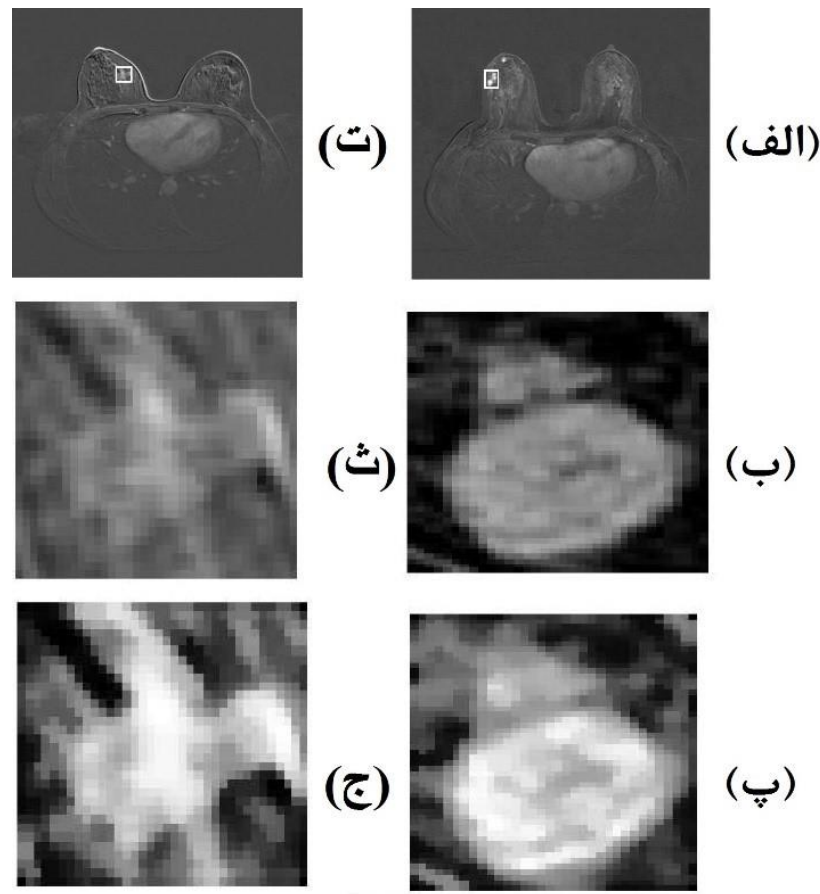

(ج)

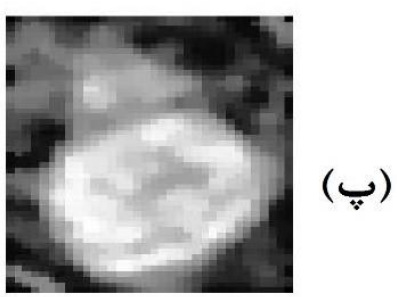

شكل r: نتايج حاصلشده از مراحل جداسازى ROI ضايعه و بهبود كنتراستى. تصاوير (الف) و (ت) تصاوير دو دادهى خام استفاده شده

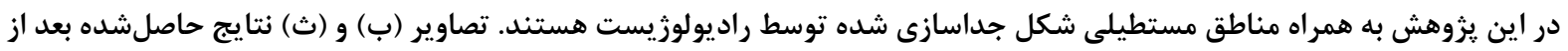

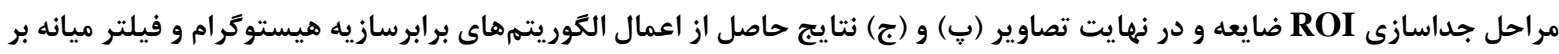
تصاوير جداسازى شده مى باشند

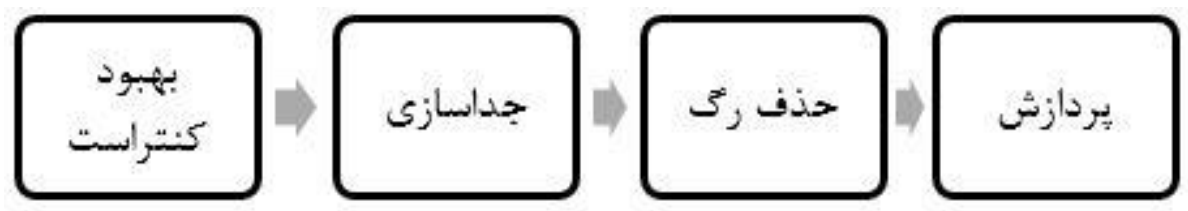

شكل r: بلوك دياترام روش جداسازى

نواحى مثبت كاذب استفاده مىشود. با انجام اين مراحل سيستم CADe ييشنهادى براى جداسازى خودكار ضايعات يستان در تصاوير MR اجرا مىشود. در اين يزوهش، مراحل مختلف بلوك دياكرام شكل ب به ترتيب در ادامه موردبررسى قرار گرفتهاند. بهبود كنتراست: در اين مرحله از سيستم CADe، بهمنظور افزايش كيفيت تصاوير و همجنين تسهيل در امر

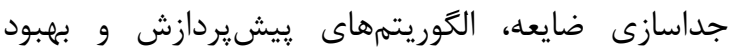
كنتراست به تصاوير اعمال مىشوند. در اين مرحله ابتدا از برابرسازى هيستوگرام(Histogram Equalization) بهمنظور بهببود كنتراستهاى ناحيهى ضايعه استفاده شده و سيس با اعمال يك فيلتر ميانه عمل حذف نويز انجام

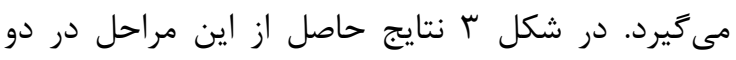
تصوير بهعنوان نمونه نشان داده شده است.
اين مرحله از الگوريتم CADe مطابق با بلوى دياگرام

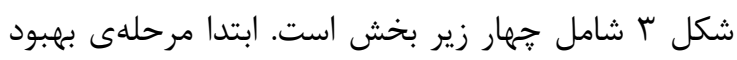
كنتراست خواهد بود كه كار حذف نويز در آن انجام مى گيرد سيس وكسلهايى بهعنوان كانتور اوليه در نظر كرفته مىشوند (ناحيه قرارگيرى اين كانتور، حساس بـ به به محل ضايعه نيست) و بهعنوان نقاط اوليهى دانه الگوريتم رشد ناحيهاى مورد استفاده قرار Point)

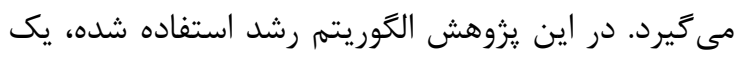

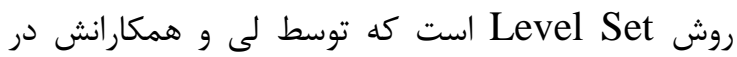
MR معرفى (Y) معده است و كارايى مناسبى در تصاوير از خود به نمايش كذاشته است. بعد از آن با استفاده از

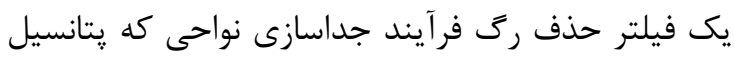
ضايعه بودن دارند انجام داده مىشود. سرانجام در مرحله

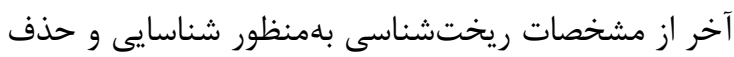


تابع انرزى قرار مى كيرد، كه درنتيجه آن به يك فرمول Level Set

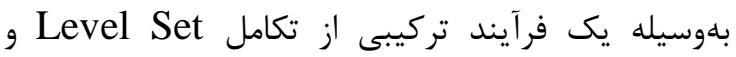

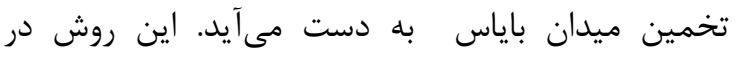
بRI

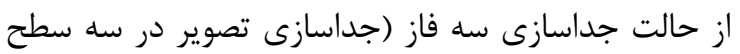
شامل ناحيه ضايعه، حاشيهى ضايعه و صفحهى زمينه)

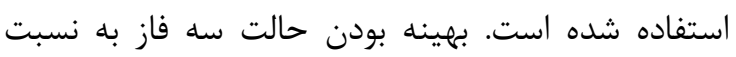
ساير حالات به صورت تجربى ثابت شده است. سيس براى حذف تشخيصهاى مثبت كاذب درمجموعهى وكسلهاى جداسازى شدهى ضايعه، ماتريس عضويت ضايعه كه توسط كاذب درمجئ وكئ

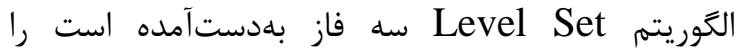
بهصورت باينرى شده و تنها در كوجكترين فاز (فاز اول)

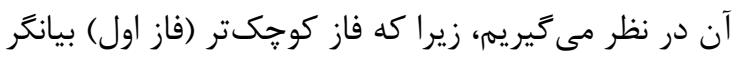

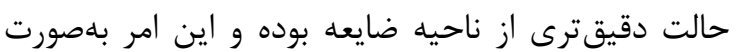
تجربى قابل تاييد است.

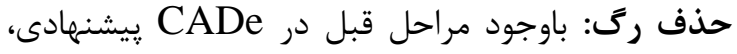

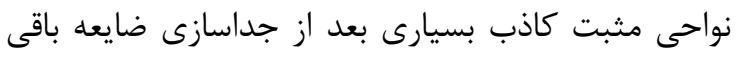

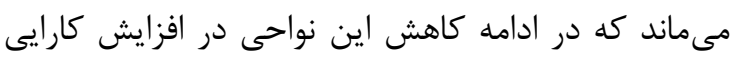
روش پيشنهادى بسيار مؤثر است. در اين كام از الكوريته

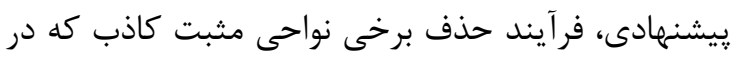

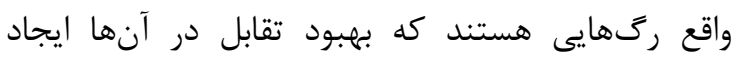

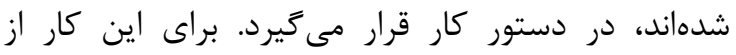

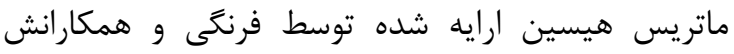

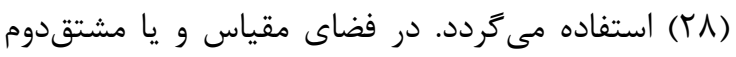
يك تصوير بلهنوان ماتريس هيسين درنظر كرفته مى شوند. مقادير ويزمى ماتريس هيسين مىتوانند بيانكر

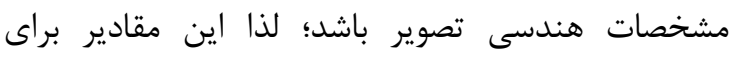
آشكارسازى ساختارهاى مختلف موجود در تصوير به كار

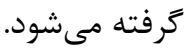

يردازش: باوجود طى مراحل قبل نواحى بالقوه باقىمانده

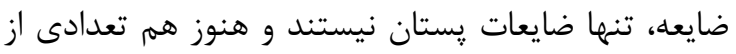

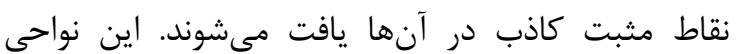
ممكن است نتايج مثبت اشتباه نظير: مصنوعات حركتى و نويز و غيره باشند. وجود اين تشخيصهاى كاذب در دريت

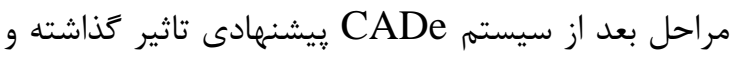

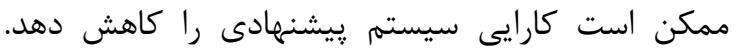
براى كاهش تشخيصهاى مثبت كاذب، يك مرحله افتراق

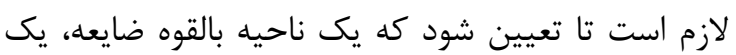

جداسازى: غيريكنواختى درشدت تصاوير اغلب به دلايل

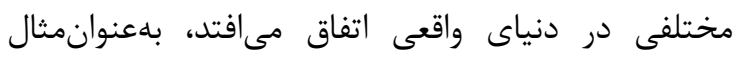

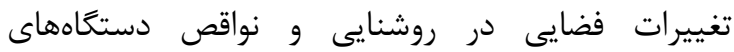

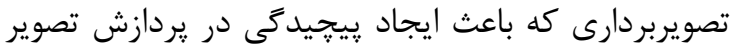

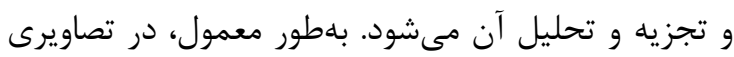
كه به هر طريقى داراى شدتهاى غير يكنواخت هستند در آنها جداسازى ضايعه ممكن است با سختى انجام يذيرد و وري

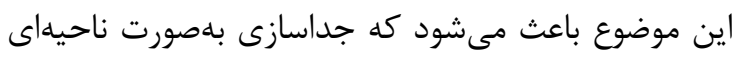
كار بسيار دشوارى شود. اين در حالثى حاست است كه عموماً

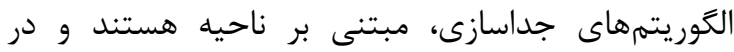
تصاويرى با شدتهاى غيريكنواخت كاربرد ندارند. بنابراين،

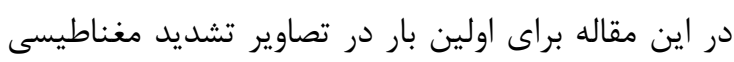

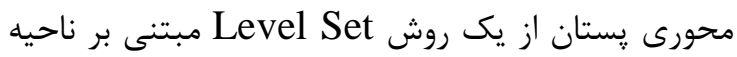

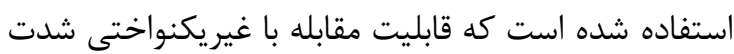

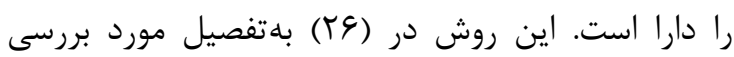

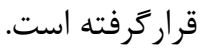

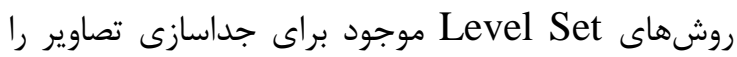
مى توان در دو طبقه اساسى تقسيمبندى نمود: مدلهاى

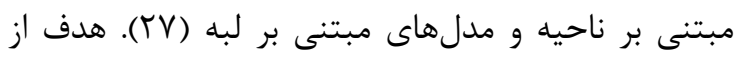

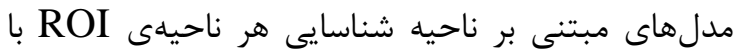

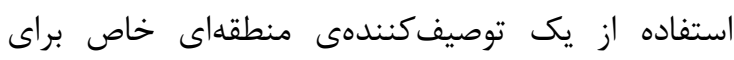

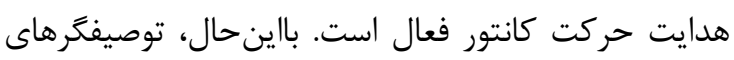
ناحيهاى در تصاوير با شدتهاى غيريكنواخت بلهصورت

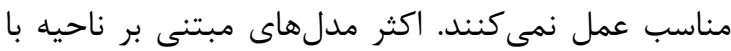

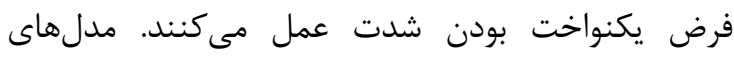
مبتنى بر لبه از اطلاعاتى كه در لبههاى تصوير وجود دارند بمنظظور جداسازى تصوير استفاده مىكنند. كه اين مدلها

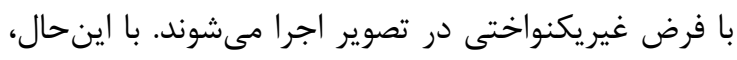
اين روشها نيز بهشدت به شرايط اوليه حساسيت دارند.

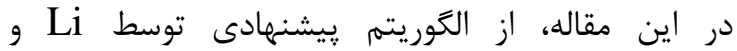

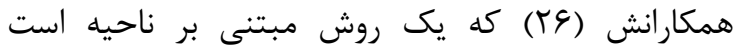

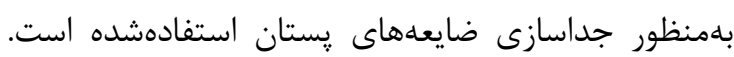
روش پيشنهادى بر روى پايخاه دادهى استفاده شده در اين

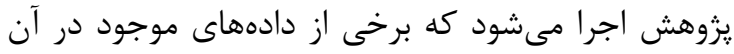

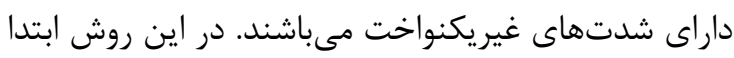

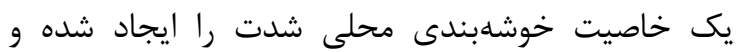

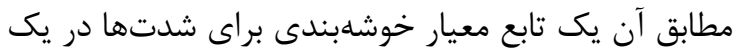
همسايكى از هر نقطه تعريف مىشود. اين معيار خوشهبندى محلى بر روى مركز همسايكى بامنظور تعريف يكى إنى 
متغيرهاى عددى به منظور توصيف تصوير مىباشد (ه山).

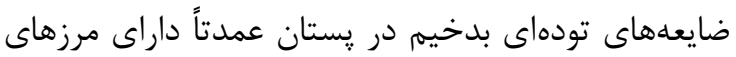

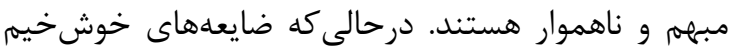

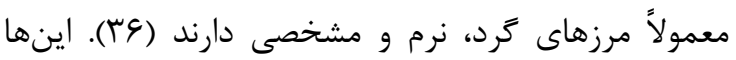

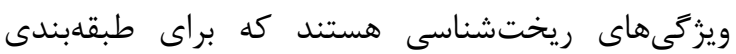
بسيار مفيد خواهند بود. ويزگى هاى يويا، بيشتر توصيف كنندهى مدتزمان وجود كنتراستهاى بهبودتقابليافته درون ضايعه هستند. اما اين قابليت در آنها وجود نداد ندارد

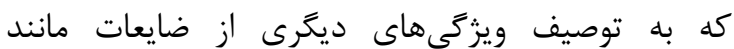

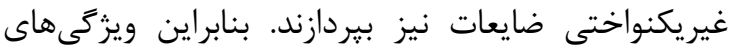

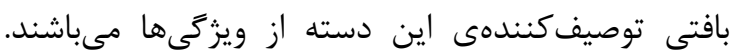
ويزگى هاى بافتى و فر كانسى بيشتر بر تركيب بافتى ضايعه

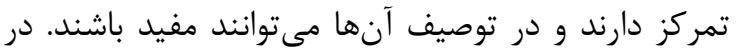

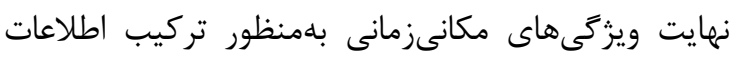

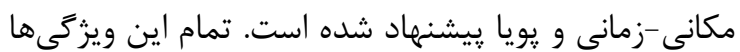
قابليت اعمال به طبقهبندى كننده راندان دارند.

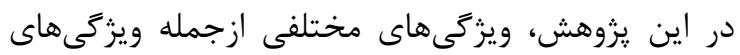

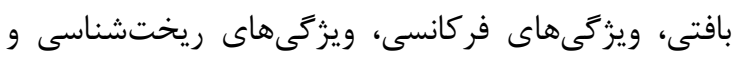

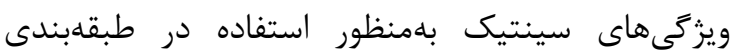
كننده استخراج و مورد استفاده قرار كرفتهاند.

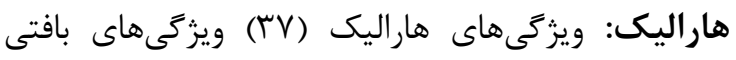

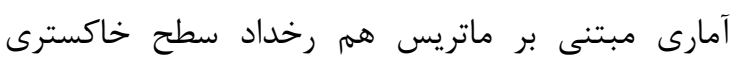

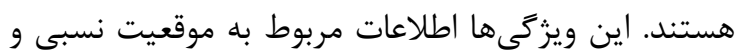

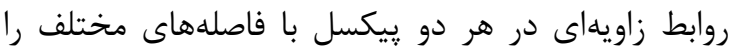

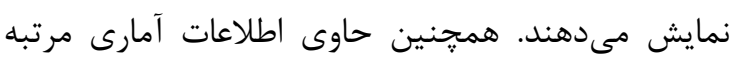

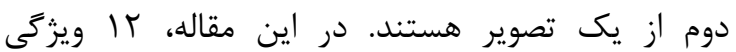

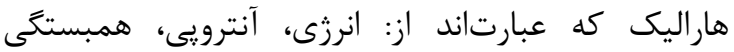
(Correlation) اينرسى (Inertia)، سايه خوشهاى (Cluster Shade)،

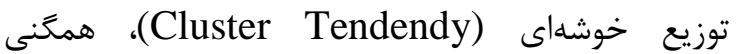

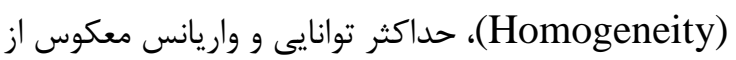

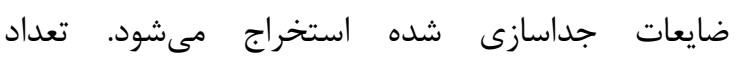
ويزگى هاى بهدستآمده از اين حالت در هركدام از نمونه

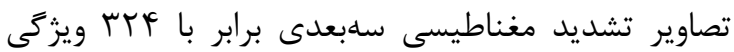
مىباشد. - مائر ماتريس طول اجراى سطح خاكسترى: در زمينهى يردازش

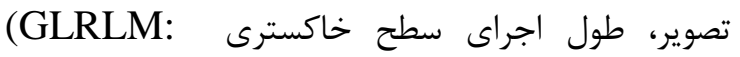
Grey-Level Run Length Matrix) بيكسل هاى متوالى كه داراى يك سطح خاكسترى يكسان
ضايعه واقعى است يا تشخيص مثبت كاذب است. بنابراين نواحى تشخيص دادهشه بلهوسيلهى يكى عملكر ريختشناسى به دو دسته ضايعه و بافت طبيعى تقسيم

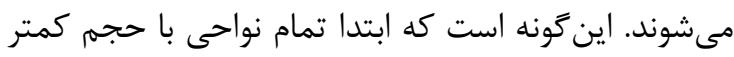

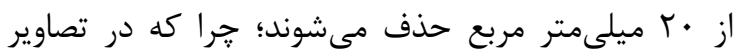
تشديد مغناطيسى استفادهده در اين يزوهش حجم تمام

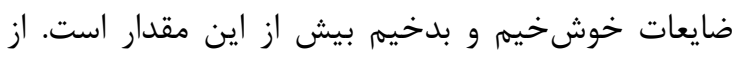

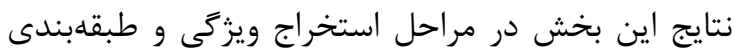

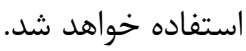

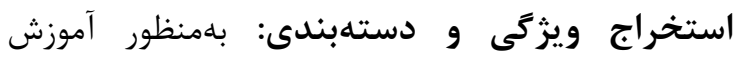
دستهبندى در اين بخش و همجِنين براى تشخيص نوع

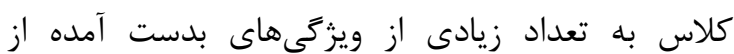

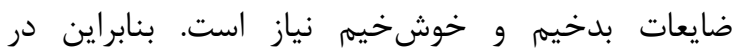
يزوهشهاى بيشين ويزگى هاى مختلفى در تصاوير تشديد

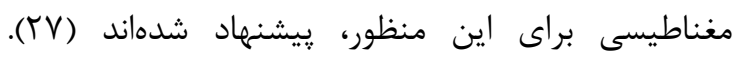
بهعنوان نمونه راديولوزيستها ضايعات مختلف را بر اساس باس باس ويزگ هايى كه فعاليت بيولوزيكى ضايعه دارد با استفاده از

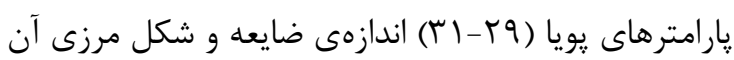

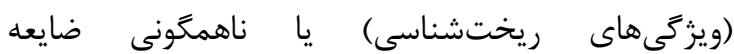

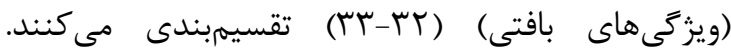
علىرغم تلاشهاى بسيارى كه درزمينهى استخراج

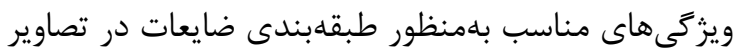
تشديد MR صورت گرفته است اما هنوز هم در مورد ويزگى هاى مناسب براى اين كار يك توافق نظر جامع

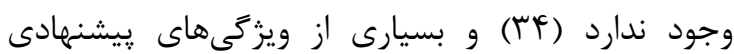

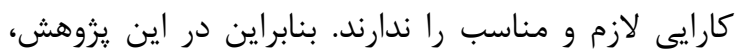

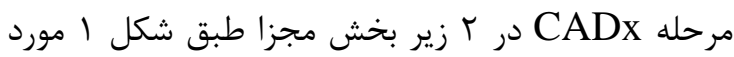
تجزيهوتحليل قرار خواهد كرفت. در مرحله اول، استخراج

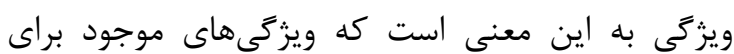

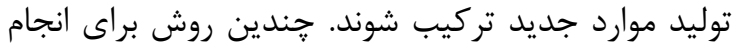

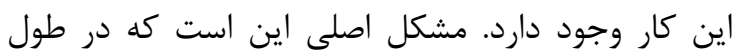

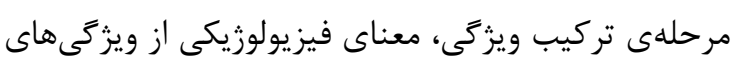
اصلى ممكن است از دست بروند. به همين منظوري

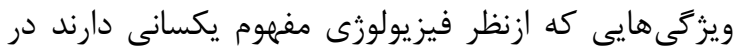

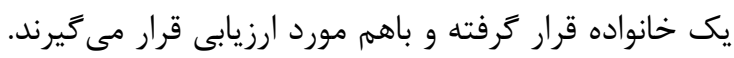
در نهايت هر خانواده به صورت جداكانه به يك دستهابندي

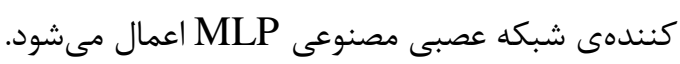
استخراج ويثگىى: در مباحث مربوط با بردازش تصوير و

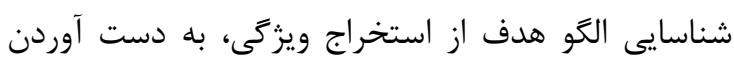




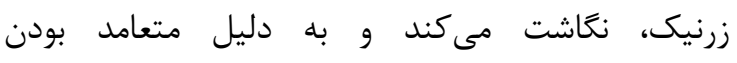
جندجملهاى زرنيك، آنها ويزگگ هايى را كه از تصوير ارايه مى كنند عموماً بدون همريوشانى هستند (·) (F).

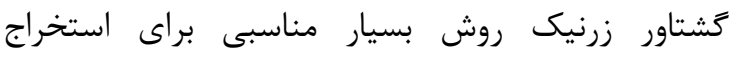
ويزَّىهاى شكل بهمنظور تشخيص تودههاى يستان ارايه مى دهند. در اين مقاله با تغيير n و m در معادله ا، تعداد

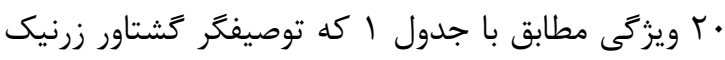

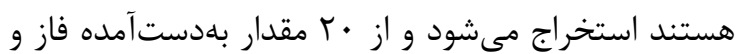

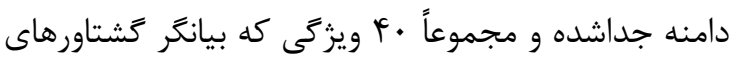
ضايعات هستند به دست مى مئيد موجك گابور: يك موجك كابور دوبعدى عبارت است از

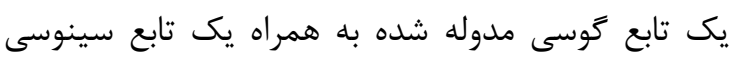

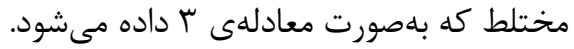
$\Psi(x, y)=\frac{1}{2 \pi \sigma_{x} \sigma_{y}} \exp \left[-\frac{1}{2}\left(\frac{x^{2}}{\sigma_{x}^{2}}+\frac{y^{2}}{\sigma_{y}^{2}}\right)+2 \pi j W x\right](\Gamma)$

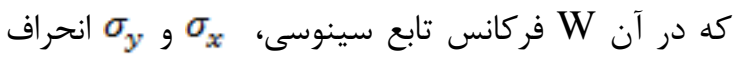
معيار مىباشند. علىرغم اين شكل كلى، هيج تاني تعريف

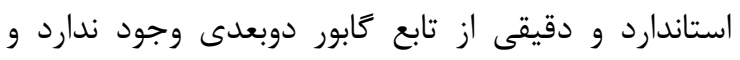
شكلهاى مختلفى از اين تابع در مقالات ظاهر شده است

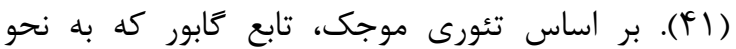

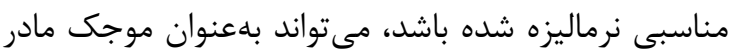

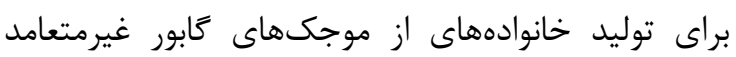

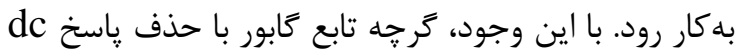

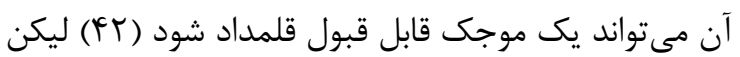

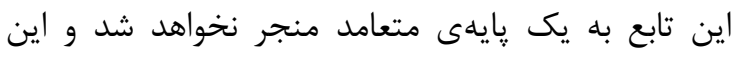
بدان معنى است كه تبديل موجك بر بايه موجك كابع نابور حاوى افزونكى است. بلرغم غيرمتعامد بودن اين خانواده

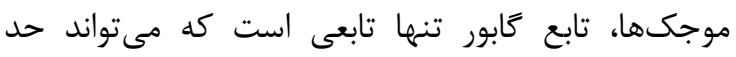
تئورى دقت تفكيك توام اطلاعات در هر دو حوزهى مكانى تابع

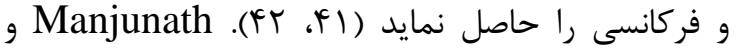

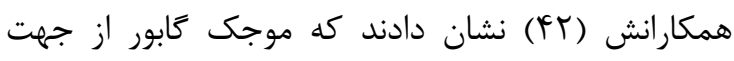
حداقل سازى عدم قطعيت دوبعدى توام بين حوزهى مكان و فركانس، يك تبديل بهينه مى باشد.
در يك جهت هستند، تعريف مىشود. بافت يك تصوير را مىتوان با استفاده از سطح خاكسترى، طول و جهت اجزا

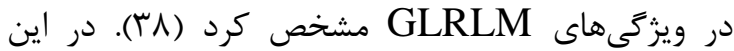

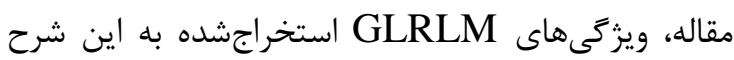
SRE: Short Run ) مىباشند: فشردهازى سريع الماى LRE: Long Run (Emphasis )، فشردهازى كند (Emphasis GLN: (Emphasis RP: ( Gray Level Non-Uniformity RLN: (Run Percentage (Run Length Non-Uniformity LGRE: Low Gray ) اجزاى سطح خاكسترى كم فيردساي

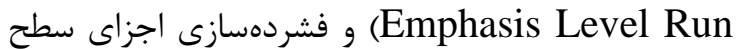

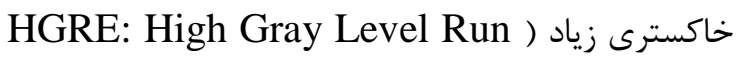
(Emphasis

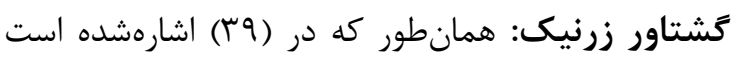
بهمنظور استخراج گشتاور زرنيك از يك تصوير، ابتدا جندجملهاى شعاعى محاسبه شده بعدازآن توابع اساسى آنى

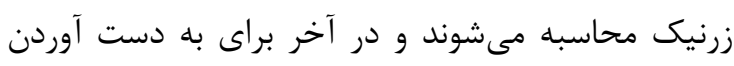

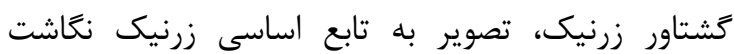

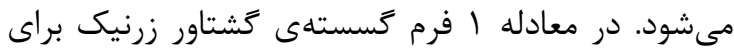
يك تصوير با N*N يُ يكسل نشان داده شده است. $Z_{n, m}=\frac{n+1}{\lambda_{N}} \sum_{c=0}^{N-1} \sum_{\gamma=0}^{N-1} f(x, y) V_{n, m}(x, y)$ $=\frac{n+1}{\lambda_{N}} \sum_{c=0}^{N-1} \sum_{\gamma=0}^{N-1} f(x, y) R_{n, m}\left(P_{x y}\right) e^{-j m \theta_{c \gamma}}$ و جندجملهاى هاى شعاعى و تابع اساسى $R_{n, m}$

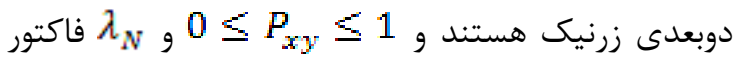
نرماليزه مىباشد. n يك عدد صحيح نامنفى است كه

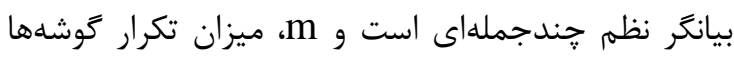
است كه تنها محدوديتى كه براى انتخاب اين مقادير وجود دارد بهصورت معادله ب است. $n-|m|=$ an even number and $|m| \leq n$ گشتاور زرنيك يك تصوير را به جند جملههاى يِيجيده

جدول ا: مومنتهاى زرنيك استفاده شده

\begin{tabular}{|c|c|c|c|c|c|c|c|c|}
\hline$r$ & 1 & p & $r$ & $r$ & $r$ & $r$ & $r$ & تعداد مومنت \\
\hline 1. & 9 & $\Lambda$ & $\mathrm{V}$ & 9 & $\Delta$ & f & $r$ & $\mathbf{n}$ \\
\hline$\cdot-\hat{r}-\Lambda$ & v & $r-r-\varphi-\Lambda$ & $1-r-\Delta$ & $y-9$ & $1-r$ & $\cdot-r-r$ & $1-r$ & $\mathbf{m}$ \\
\hline
\end{tabular}


عمودند و فضاى بـالاتر را تشكيل مسىهنـد. اخـر

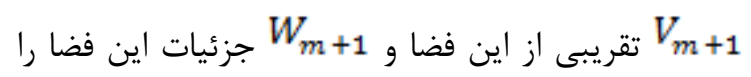

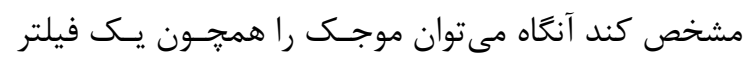
بانك در نظر كرفت كه به كمك تابع ب كليات (قسمت

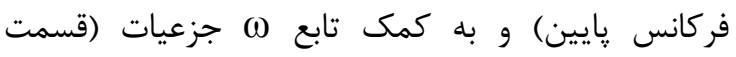

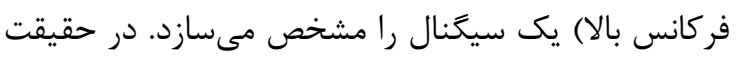

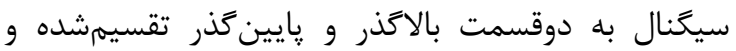

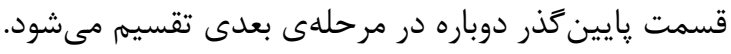

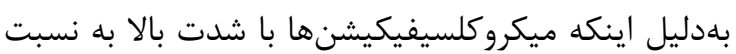

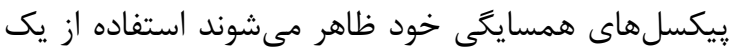
تبديل موجك دوبعدى بلمنظور حفظ كليات تصوير

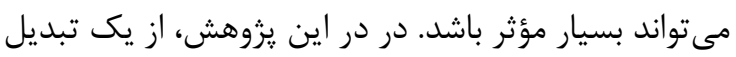
موجك دوبعدى بهمنظور تجزيلهى تصوير استفاده شده و اين تجزيه تا ينج مرحله انجام كرفته است و براى نتيجهاى كه از كليات تصوير حاصل مى تردد اعمالى نظير ميانكين،

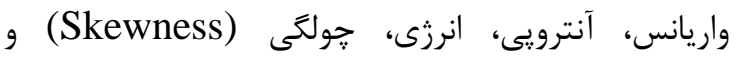
كشيدگى محاسبه مى

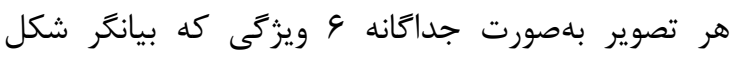

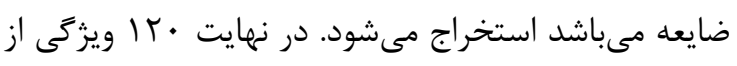
تصاوير حاصلشده استخراج مىشود. ويزگى بعدى نسبت يُيك سيگنال به نويز است كه با در نظر كرفتن تصوير

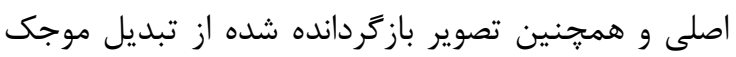
به دست مىآيد و همجنين ويزگى آخر آنر نيز ميانكين

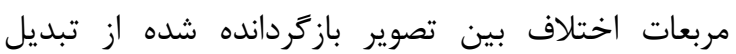

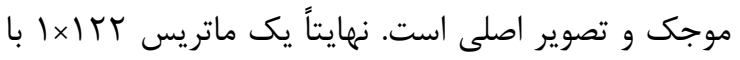
استفاده از تبديل ويولت حاصل مىشود.

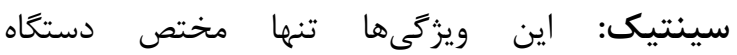
تصويربردارى MR بوده و در روشهاى تصويربردارى ديخر

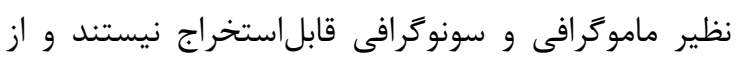
رشته تصاوير يويا كه بعد از تزريق ماده حاجب كابت كادولينيوم

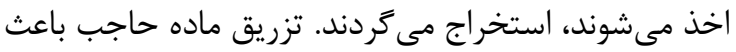

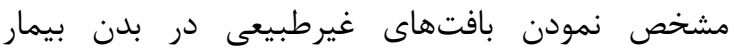

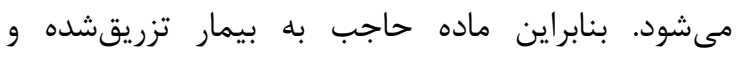
تصويربردارى در جندين مرحله، به فاصله إنهاى زمانى معين

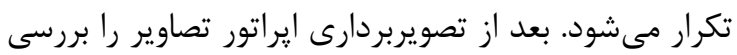

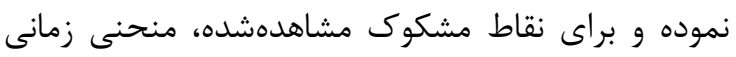

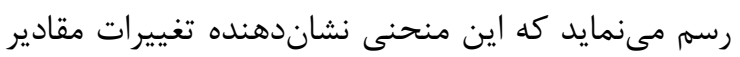
شدت ييكسلها برحسب زمان، در اثر تزريق ماده حاجب إنب
ويزگى هاى گابور بر اساس گروهى از موجكها در جهتها

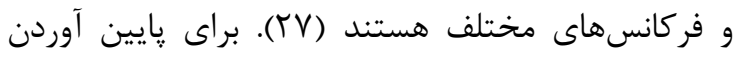
هزينههاى محاسباتى درحالى كه دقت هم حفظ شود در

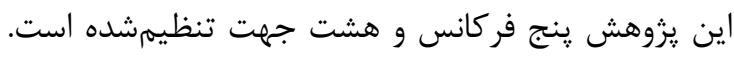

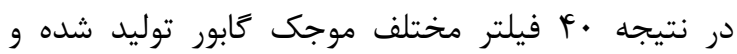
سيس كانوولوشن موجك كابور با تصوير اصلى محاسبه

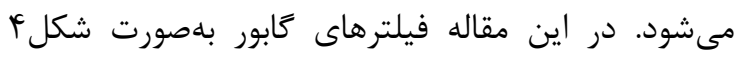

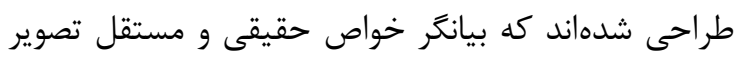
هستند. براى نتايج به دست آماده توسط فيلترهاى نشان دادهشه در شكل Fٔ بلمنظور استخراج ويزَى در هر سطر

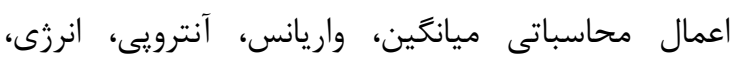
جولكى و كشيدگى بلهورت مجزا محاسبه مىشوند. در

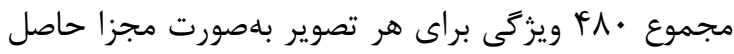

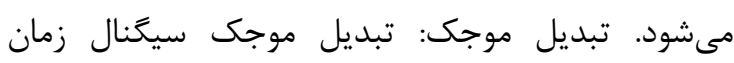

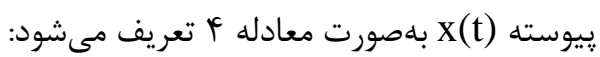
$w_{x}(a, b)=|a|^{\frac{-1}{2}} \int_{-\infty}^{\infty} x(t) E\left(\frac{t-b}{a}\right) d t$

(

در اين رابطه، (X) f يك موجك مادر است كه توابع تغيير

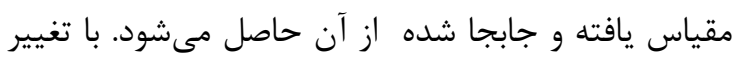
مقادير a و b مقياس تغيير كرده و جابجا مى تردد. بـابـا

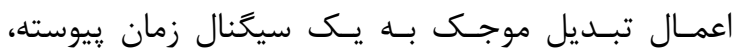

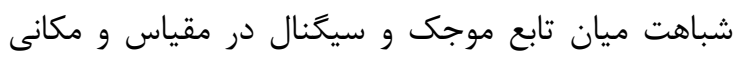

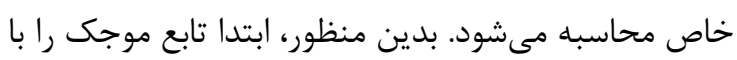
مقياس ثابتى در ابتداى سيخنال ضرب كرده تا نتيجه

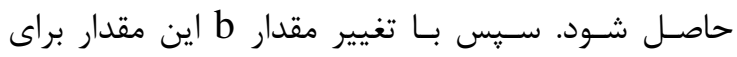

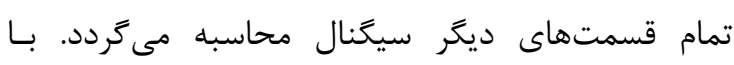

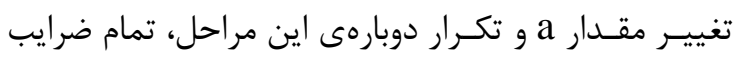

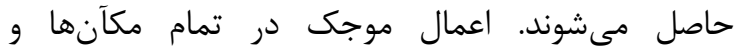

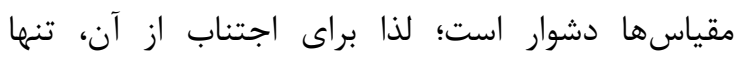

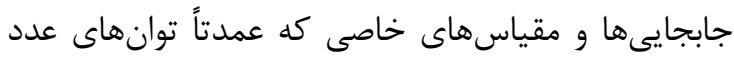

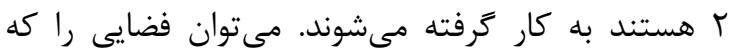

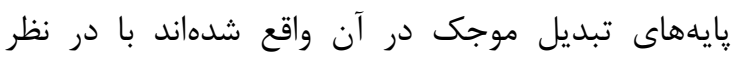

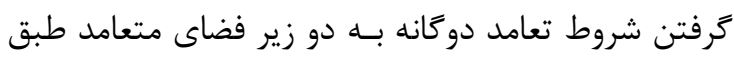
معادلات ه، و و V تقسيم كرد. $V_{m}=V_{m+1} \oplus W_{m+1}$

$V_{m}=\operatorname{span}\left(\varphi\left(2^{-m} \mathrm{t}-\mathrm{n}\right), \mathrm{n} \in \mathrm{Z}\right)$

$W_{m}=\operatorname{span}\left(\omega\left(2^{-m} t-n\right), n \in Z\right)$

به اين معنا كه 


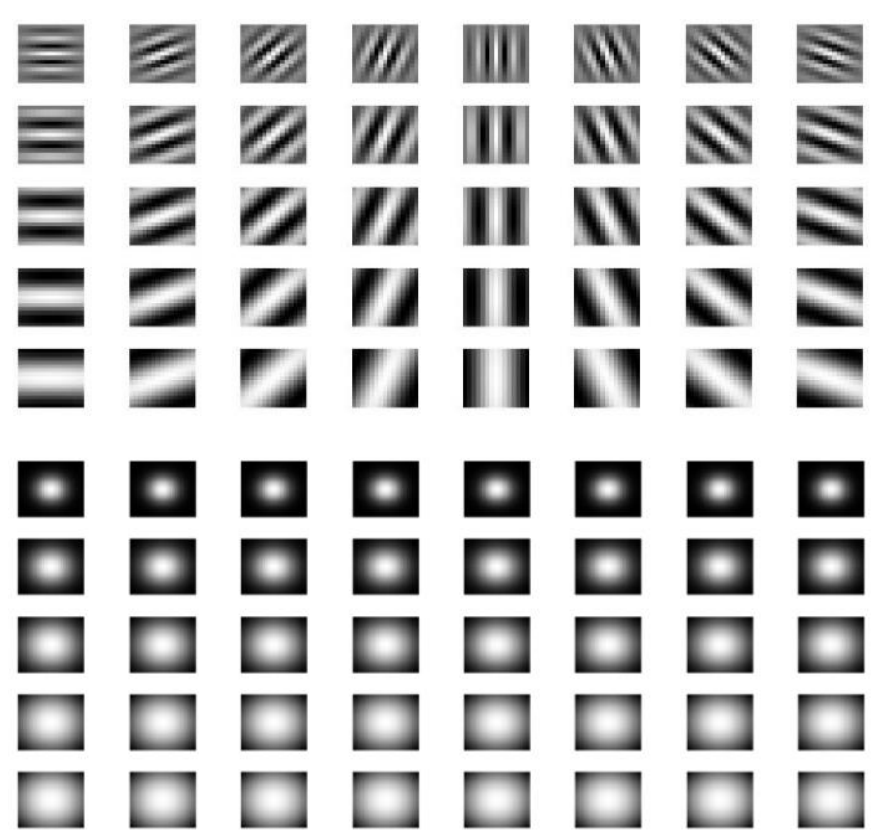

شكل Fا: تصاوير حقيقى و مستقل حاصلشده از معادلهى كابور با ينج فركانس و هشت جهت تنظيم. ه رديف اول تصاوير حقيقى و ه

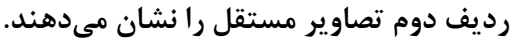

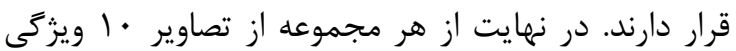

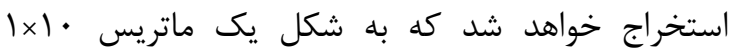
نمايش داده مىشوند. كابور - هاراليك: و اما نوآورى اين مقاله معرفى دستهى جديدى از ويزگى ها است كه از تصاوير در فضاى دو بعدى استخراج مىشود. اين ويزگى ها با تركيب نقاط قوت ويولت

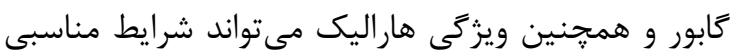
را به جهت طبقهبندى ضايعات بدخيم و خوش خيم فراهم

در تمام تصاوير ابتدا مطابق با بخش لأ، ا، ه، ب عمل

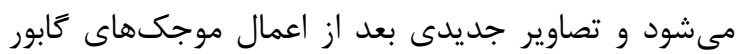

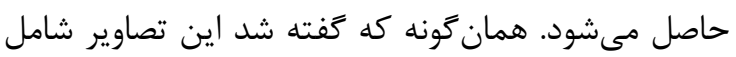

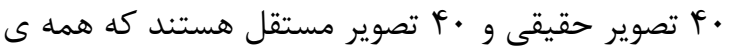
اين تصاوير در كنار هم به صورت يك تصوير سهبعدى

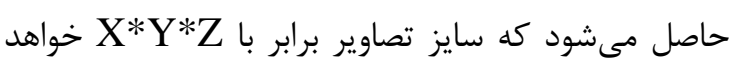

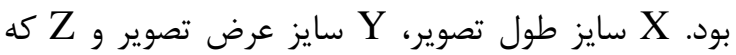

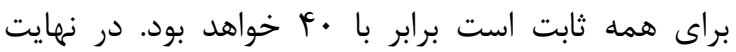

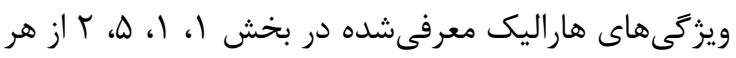
يك از تصاوير سهبعدى حاصل شده استخراج خواهد شد.

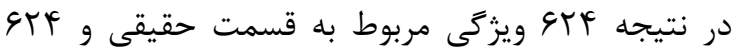
ويزگى نيز مربوط به قسمت مستقل تصاوير حاصل خواهد
با تزريق اين ماده اكثر سرطانها، در تصاوير بهصورت نواحى روشن ديده مىشوند. اگر ماده حاجب كادولينيوم

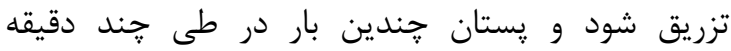

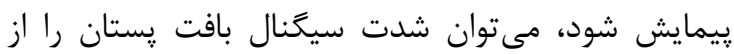
يك ريمايش تا ييمايش بعدى مقايسه نموده و تغييرات

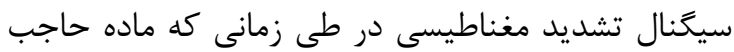
درون يستان جريان داشته و به بافتها و ضايعات نفوذ

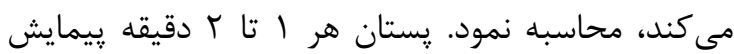
شده و منحنى تغييرات شدت سيخنال برحسب زمان رسم

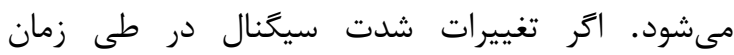

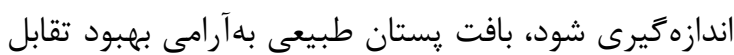
مىيابد. ضايعات خوشخيم در طى جند دقيقه سريع بهبود تقابل يِيدا مى كنند. ضايعات بدخيم نيز سريع بهبود

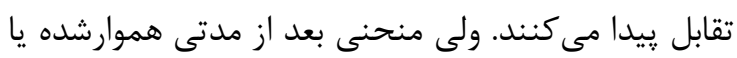

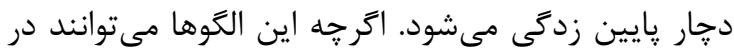
ارزيابى يك ضايعه كمك كنند، ولى همريوشانى هاى مهرى هم وجود دارد كه باعث مىشوند تا الكوهاى بهببود تقابل

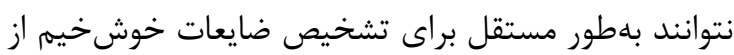

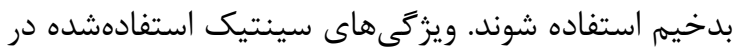
اين يزوهش ميانخين و انحراف معيار ناحيهاى از ضايعه هستند در تصاوير تشديد مغناطيسى كه در در زمآنهاى مختلف گرفتهشدهاند كه در بيشترين بهبود تقابل خود 
باياس، در هر بخش از اين يزوهش بلمنظور ارزيابى

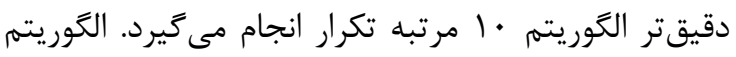

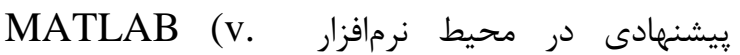
يم2018a)

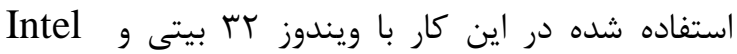
(4GB RAM) Windows, Core i7 $2.53 \mathrm{GHz}$ 7 اجرا شده است. زمان اجراى حدودى براى عأ عدد از دادهها بهصورت ميانخين برابربا ب ثانيه است. معيارهاى ارزيابى: در هر مرحله معيارهاى خاصى براى ارزيابى استفاده مىشود. در يزوهشهاى مختلف، براى ارزيابى روشهاى جداسازى، نتايج حاصلشده از الكوريتم با يك مرجع مقايسه مىشود. مرجع تصوير جداسازى شده در اين يزوهش همان مرز ضايعه و ديكر مناطق يستان مىباشد كه بهصورت دستى توسط يك راديولوزيست رسم

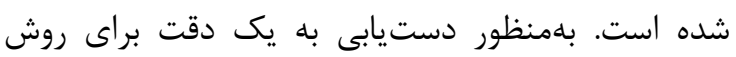
جداسازى، از ضريب شباهت دايس (JC: و وريب جاكارد Similary Coefficient) Jaccard Coe IC $=\frac{A \cap M}{A \cup M} \times 100$

$I C=\frac{A \cap M}{A \cup M} \times 100$

كه در اين روابط، A و M حجم جداسازى شده حاصل از روش خودكار و روش دستى است. در مرحله بعدى، كه

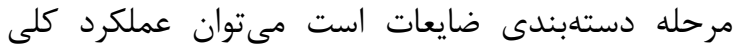
سيستم در تشخيص صحيح و شناسايى نوع ضايعه ارزيابى

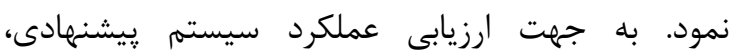
يارامترهايى در نظر كرفته مىشوند كه مقدار آنها ميزان

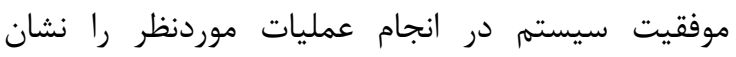

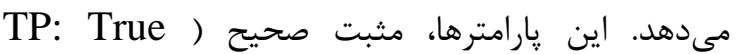
Positive)، مثبت كاذب (FP: False Positive)، منفى صحيح (TN: True Negative)، منفى كاذب (PN)،

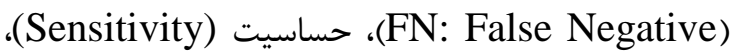
دقت (Accuracy)، خاصيت (Specificity)، صحت، مقدار اندازه f مىباشد كه به شرح زير بيان مىشوند: Sensitivity $=$ recall $=\frac{T P}{T P+F N^{\prime}}$

$$
\text { Specificity }=\frac{T N}{T N+F P^{\prime}}
$$

دستهبندى: اين مرحله بهمنظور دستهبندى و تشخيص اتوماتيك ضايعات بدخيم و خوشخيم از هم، بهوسيله بهمنيله ويزگى هاى استخراجشده در بخشهاى قبلى در نظر گرفته

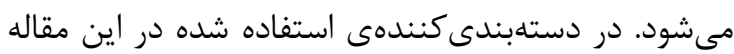

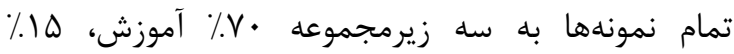

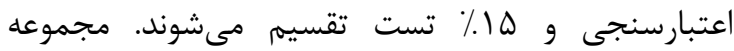
آموزش براى آموزش شبكه عصبى استفادهده و مجموعه

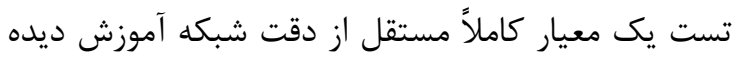
شده را فراهم مى كند و مجموعه اعتبارسنجى نيز به منظور ارزيابى مسير آموزشى درنظر كرفته شدها مجاند. اطلاعات تنها در يكجهت و آن هم رو به جلو، از كرئهاى ورودى، از طريق كرههاى ينهان و كرهماى خروجى حركت

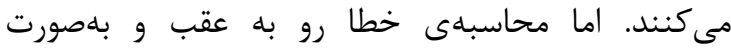

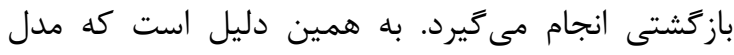

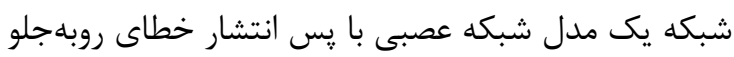
است. MLP يك مدل شبكه عصبى مصنوعى است كه به بـ مجموعه دادههاى ورودى را بر روى مجموعهاى از از خروجى هاى مناسب نمايش مىدهد. لايه از گرهها در يك لايه كراف مىباشد، هر لايه بلهطور

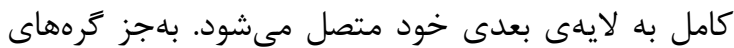

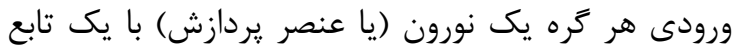

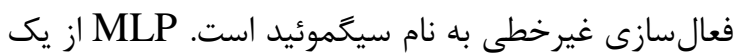
تكنيك يادگيرى نظارتشده به نام يس إن انتشار در

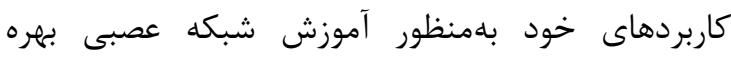

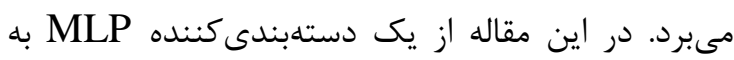

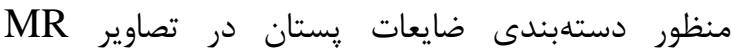
بلهورت خوشخيم و بدخيم استفاده شده است.

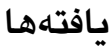

در اين بخش، ابتدا معيارهاى ارزيابى كه در سيستم ييشنهاد شده در اين يزوهش مورداستفاده

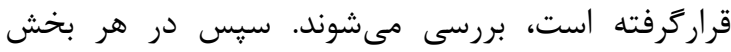

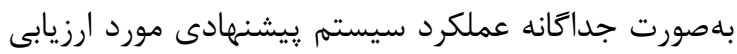
قرارَرفته و با ساير يزوهشهاى مشابه مقايسه شده و برانه برترى آن نسبت به ساير يزوهشها بيان مىشود. در در اين

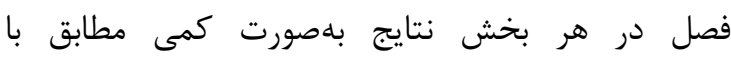

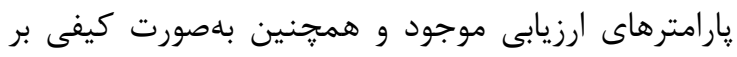

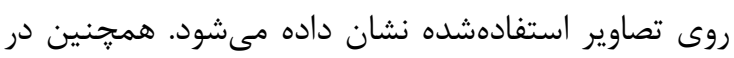
آخر بهمنظور دستيابى به يك نتيجه قابل اعتنا و بدون 
بهدستآمده از يزوهشهاى ديكر نيز كزارششده است.

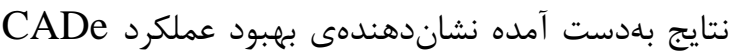
ييشنهادى در اين يزوهش در مقايسه با ساير روشها

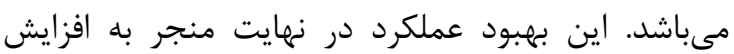

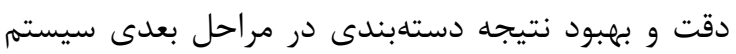
CAD يشنهنهادى خواهد شد. نتايج كيفى جداسازى نيز در جهار نمونه از دادهادهاى

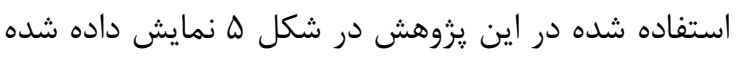

نمونههاى موجود در شكل ه هر دو نوع ضايعه خوشخيم

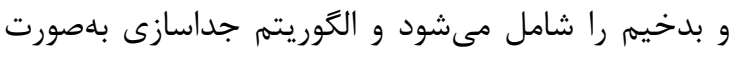

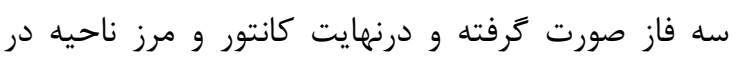
شكلهاى ستون سمت راست بر روى تصوير اصلى نمايش دادهده است. سيس در ستون سمت جֶٍ نيز ناحيهى جداسازى شدهى نهايى بهصورت يك تصوير باينرى نشان داده شده است

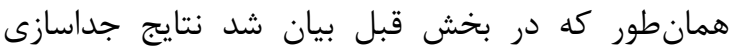

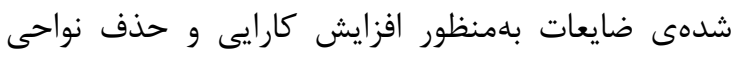
مثبت كاذب به يك الكوريتم يردازشى و حذف رى رد داده مى شود كه درنهايت منجر به حذف نواحى مثبت كاذب و همجنين حذف رگ رهاى بهبود تقابل يافته مىشود.

$$
\text { Accuracy }=\frac{T P+T N}{F N+T P+T N+F P^{\prime}}
$$

$$
\text { Precision }=\frac{T P}{F P+T P}
$$

$$
f-\text { measure }=\frac{2 \times \text { recall } \times \text { precision }}{\text { recall }+ \text { precision }}
$$

ارزيابى سيستم CADe: ازآنجايى كه جداسازى دقيق ضايعه يستان تاثير بسيارى در فرآيند تشخيص نوع ضايعه

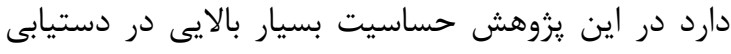

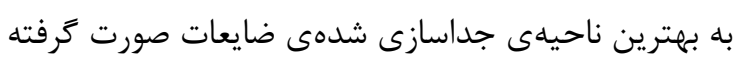

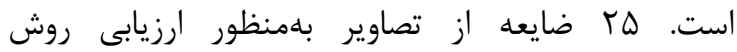
جداسازى يِشنهادى در اين يزوهش استفاده شده است.

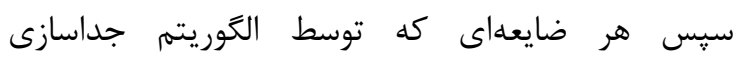

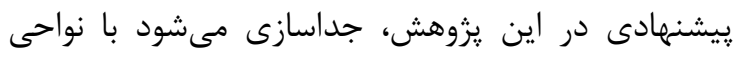

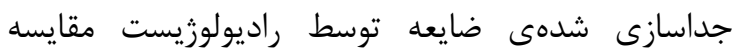

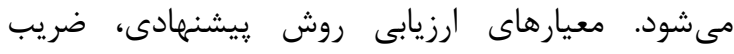

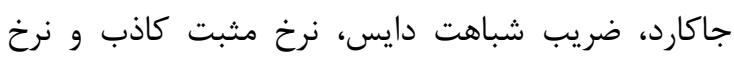

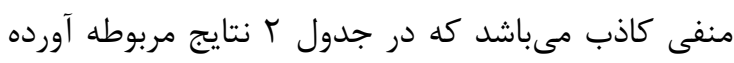

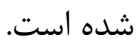
علاوه بر اين بلمنظظور مقايسه نتايج با ساير روشهاى

\begin{tabular}{|c|c|c|c|c|}
\hline FNR & TNR & DSC & $\mathrm{JC}$ & روش جداسازى \\
\hline- & $9 / 10$ & - & - & جانَ (FT) \\
\hline- & f & - & - & كوبر (FF) \\
\hline - & $\Delta / r q$ & - & - & فولادى وندا (r山) \\
\hline$\cdot / 1 \wedge 9 \Delta$ & $\cdot / \cdot V T F$ & - INATF & - IATYT & اسكندرى Kmeans (fD) \\
\hline$\cdot / \cdot 119$ & $\cdot / \cdot F \Delta V$ & .19199 & $\cdot|A F \lambda|$ & اسكندرى FCM (FA) \\
\hline$\cdot 11 \cdot k r$ & .1 .490 & $.19 T 49$ & - /ADHA & روش بيششنهادى \\
\hline
\end{tabular}

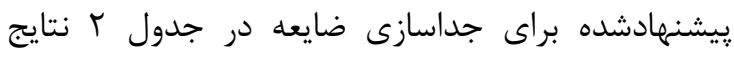

حدول r: مقايسه عملكرد سيستم CADe يِيشنهادى در جداسازى ضايعات با روشهاى پِيشين

يزوهش از شبكه عصبى تك لايه استفاده شده است كه

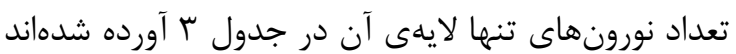

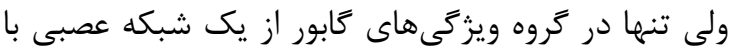

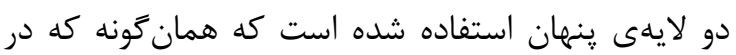

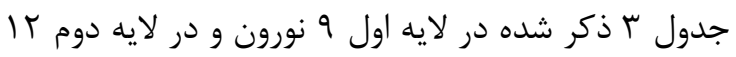
نورون وجود خواهند داشت.
ارزيابى سيستم CADx: در اين يزوهش براى ارزيابى،

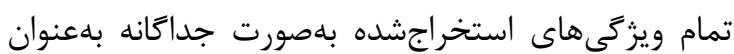

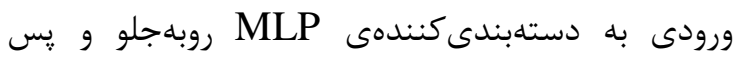
انتشار خطا با الگوريتم يادگيرى لونبرى ماركوارث اعمال

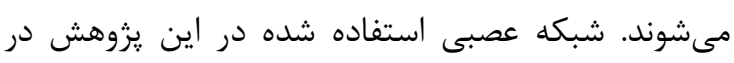
شكل 9 با ذكر تمام تنظيمات مربوط به آموزش آورده شده است. در تمام گروههاى ويزگگىهاى استفاده شده در اين 

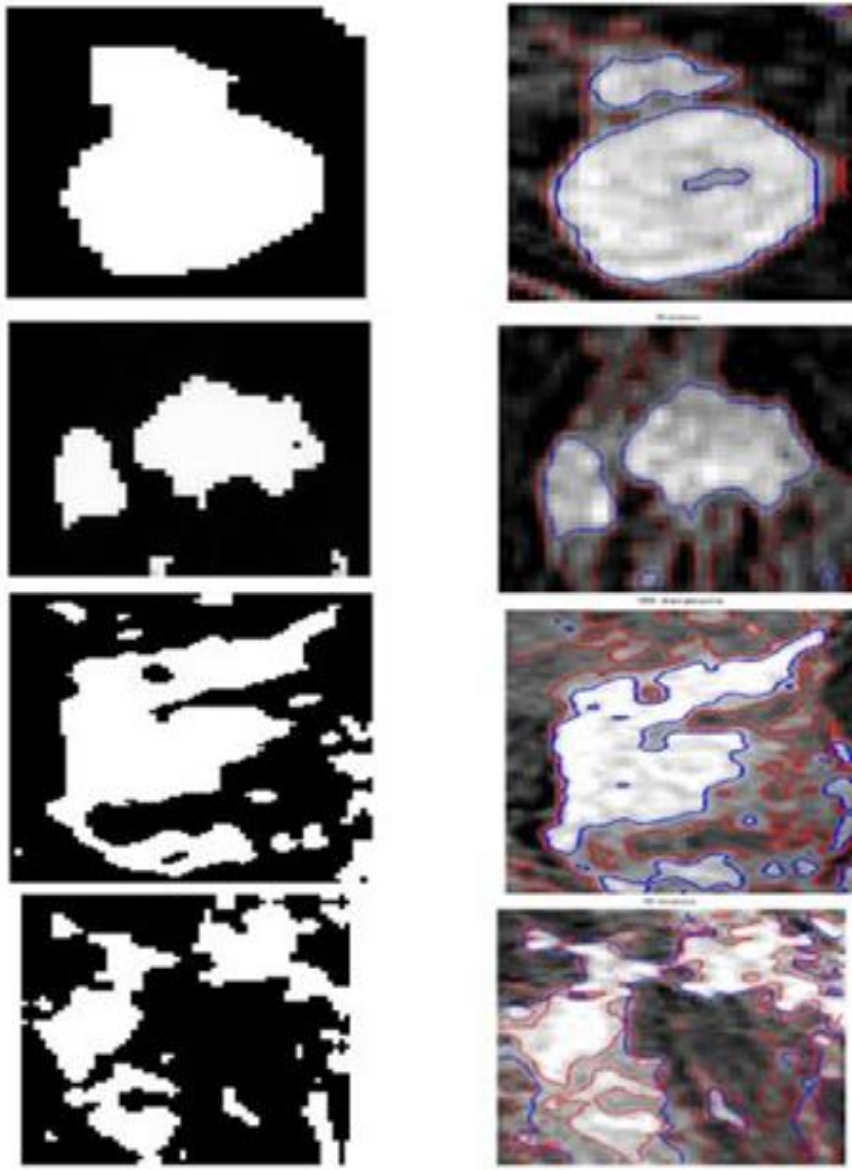

شكل ه: نتايج الكَوريتم جداسازى براى دو نمونه ضايعات بدخيم و خوش خيم در جهار تصوير.

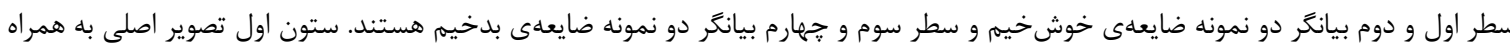

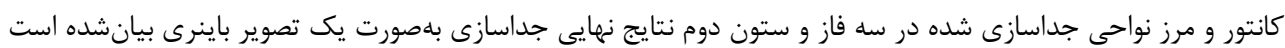

جدول r: مقايسه يارامترهاى ارزيابى با تفكيك ويزَّى ها بهصورت جداكانه بادر نظر كرفتن

\begin{tabular}{|c|c|c|c|c|c|c|c|c|}
\hline $\mathbf{A U C}$ & F اندازه & Precision & دقت & خاصيت & حساسيت & تعداد نورون & ويثَى & نوع ويزگى \\
\hline .1919. & $\Lambda \& / T V$ & $\Lambda \Lambda / \Delta V$ & $N N / 1 Q$ & $91 / 7 \wedge$ & $\Delta F / \cdot q$ & 1. & GLRLM & بافتى \\
\hline - IAVDS & $\Lambda F / \lambda$ & $\Lambda T / \cdot \Lambda$ & $\Lambda \Delta / V$ & $\wedge \Delta / 19$ & $\Lambda \& / T \Delta$ & 11 & مومنتهاى زرنيك & بافتى \\
\hline.$/ 9 \wedge V K$ & $9 \Delta / 4 r$ & $9 \&|\Lambda|$ & $99 / \pi 1$ & $91 / \cdot 9$ & $94 / 1$ & ir & هاراليك 3D & بافتى \\
\hline - /9ves & ^9/19 & $94 / 4 \&$ & $94 / 90$ & $9 / / 1$. & $\Lambda F / 19$ & $\wedge$ & ريختشناسى 3D & شكل \\
\hline . $/ 9 \Delta F G$ & $\wedge 9 / \wedge f$ & $\Lambda N / \vee I$ & $q \cdot 111$ & $q \cdot / v \wedge$ & 91 & q & كابور & فر كانسى \\
\hline . $19 \Delta T Y$ & ᄉ / VF & $\Lambda \& / V I$ & $9 \cdot 199$ & $\Lambda N / \Lambda)$ & ז & ir & ويولت & فر كانسى \\
\hline - / $9 \vee \Delta V$ & $95 / 19$ & $19 / 19$ & QT/VG & $q \cdot / v \cdot$ & $9 \Delta / 41$ & $\wedge$ & كابور -هاراليك & تر كيبى \\
\hline - $/ 99 \Delta \Lambda$ & $q \cdot / q q$ & $19 / 9 \Delta$ & $91 / 49$ & $91 / 9 \wedge$ & $91 / T \Delta$ & $\Lambda$ & كَابور -هار اليى (حقيقى) & تركيبى \\
\hline - /AVqf & $91 / 5 \wedge$ & GY/VF & $\Lambda N / \cdot r$ & $\Lambda F / \cdot q$ & $\wedge 9 / \wedge \wedge$ & $\Delta$ & سينتيك & سينتيك \\
\hline
\end{tabular}

نشده است در مقابل براى جلوكيرى از بيش برازش در هر

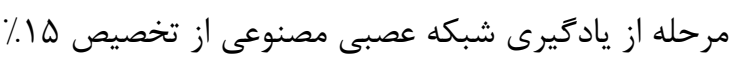
دادهها به عنوان دادهاى اعتبار سنجى استفاده شده است.
لازم به ذكر است در اين يزوهش به دليل بررسى ميزان

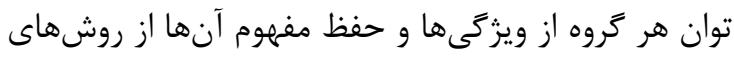

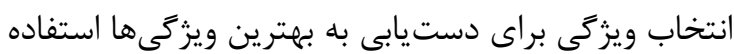


يزوهش دو ويزگى جديد تحت عنوان گابور - هاراليك (حقيقى) و كابور -هاراليك (مستقل) نيز براى اولين بار

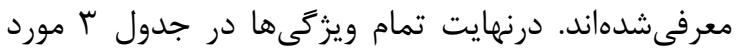

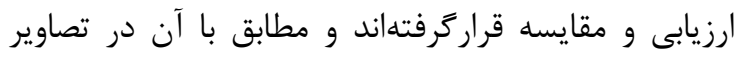
دوبعدى ويزَّى هاى كابور - هاراليك (حقيقى) از نظر دقت، مقدار اندازه f f AUC بالاترين ميزان كارايى را دارد و اما درصورتى كه اين مقايسه با تصاوير سهبعدى نيز صورت

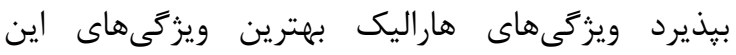

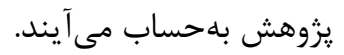

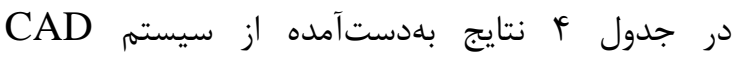

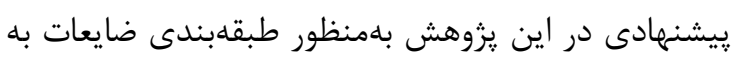

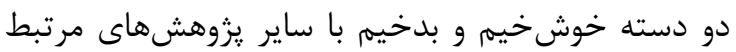

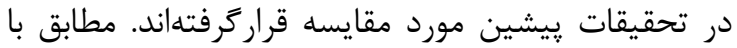

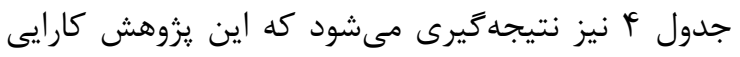

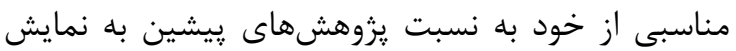
كذاشته است.
همجنين براى هر گروه از ويزگىها، · ل مرتبه الكوريته

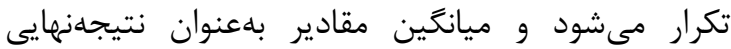
كزارش خواهد شد. تعداد تمام ضايعات تودهاى

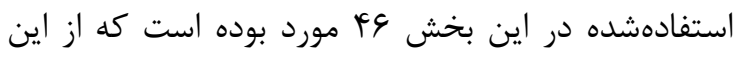

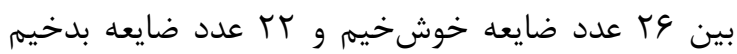
مىباشند. براى بررسى كارايى ويزگكىهاى استخراجشده،

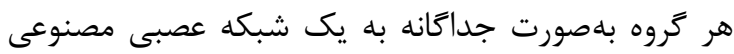

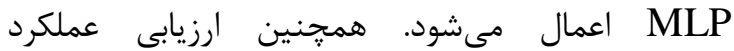
دستهبندى كننده از معيارهاى دقت، صحت، حساسيت،

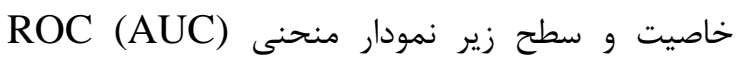
استفاده شده است. همانطور كه در جدول ب نشان داده شده، ويثز شىهاى

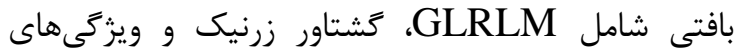
هاراليك به همراه ويزگى هاى فركانسى شامل كابور

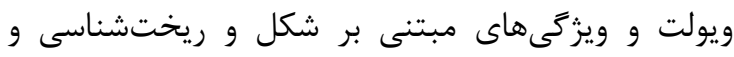
ويزگى هاى سينتيك از تصاوير استخراج شده است. در اين

\begin{tabular}{|c|c|c|c|c|c|}
\hline Precision & دقت & خاصيت & حساسيت & تعداد داده & يزوهش \\
\hline $19 / 19$ & $9 T / V 9$ & $q \cdot / v \cdot$ & $9 \Delta / 4)$ & is & اين يزوهش \\
\hline $1 \mathrm{~N} / 19$ & $9 \cdot 191$ & st & १७ & $\Delta \varphi$ & (f\&) Abdolmaleki \\
\hline $9 \cdot 11$. & ^৭/। & GT & १V & $\pi$. & (rا) Abdolmaleki \\
\hline $9 \Delta / V I$ & $\wedge$. & VT & 94 & ira & $(r F)$ Juntu \\
\hline VN/TS & $V Q / T G$ & $q 4$ & $\Delta F$ & 99 & (rF) McLaren \\
\hline- & 9. & $\wedge$. & १४ & Gr & (FV) Newel \\
\hline - & $\Lambda$ & $\Lambda$ & $\Lambda \Lambda$ & 90 & $(\boldsymbol{F} \wedge)$ Huang \\
\hline- & - & 11 & $\Lambda F$ & rgF & (₹q) Luchta \\
\hline - & 9. & Ar & 90 & (1) & $(r \cdot)$ Agner \\
\hline- & $\wedge \Delta$ & Ar & $\wedge \vee$ & 9 . & (ఎ•) Honda \\
\hline- & 99 & 94 & १४ & $11 \%$ & (Al) Rasti \\
\hline - & 94 & $1 \cdots$ & $\Lambda$ & $\Delta F$ & فولادىوندا (J山) \\
\hline- & vi & rv & $9 \Delta$ & 4. & اسكندرى (FD) \\
\hline
\end{tabular}

بالا و عدم تابش يونى در مقايسه با اشعهى ايكس بحث

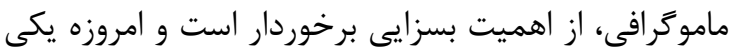

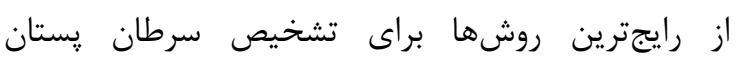

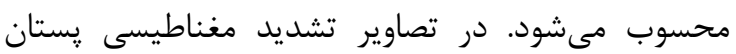

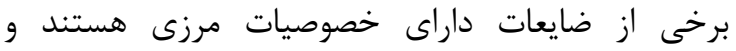

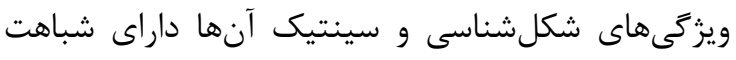
يكسان در بين ضايعات خوشخيم و بدخيم هستند و

سرطان يستان شايعترين نوع سرطان و همجنين دومين

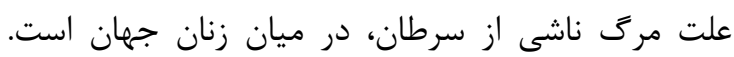
تصويربردارى تشديد مغناطيسى يك روش تصويربردارى يزشكى مناسب بهمنظور غربالكرى و تشخيص سرطان ئرئ

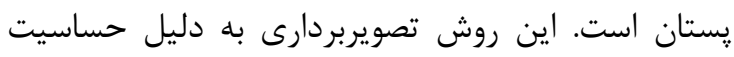


ضايعه استفاده مىشود. ابتدا از روشهاى برابرسازى هيستوكرام و فيلتر ميانه براى بيشيردازش

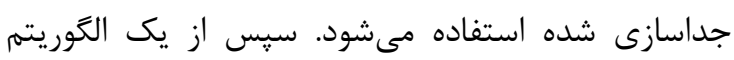

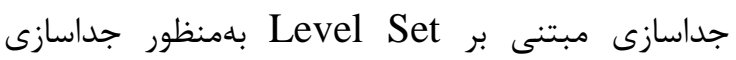
ضايعات استفاده مىشود. اين الكوريتم برخلاف ساير بنارين روشهاى موجود جداسازى ضايعات يستان را با در نظر داشتن غيريكنواختى درشدت تصاوير انجام مىدهد. دران دران ادامه از يك فيلتر حذف رى، فرايند جداسازى نواحى كه يتانسيل ضايعه بودن را دارند انجام مى گيرد و با استفاده از مشخصات ريختشناسى نواحى مثبت كاذب در هر تصوير

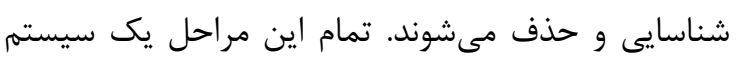
CADe بررسى كارايى آن، بايد نتايج حاصلشده با ضايعاتى كه بلهورت دستى توسط راديولوزيست جداسازى شده است مورد مقايسه قرار كيرد.
قضاوت خوشخيمى و يا بدخيمى در آنها بسيار دشوار است. در جنين مواردى به ويزگى هاى توصيفى بيشترى براى تشخيص دقيقتر نياز است. بنابراين وجود سيستمى لهى

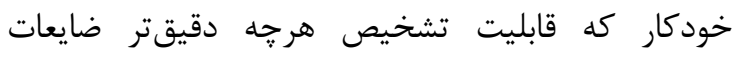
خوش خيم و بدخيم را داشته باشند، مىتواند كمك شايانى را در تصميم گيرى به يزشكان برساند و دقت تشخيص يزشك را بالاتر برده و همجنين سير برد درمان بردان بيمارى نيز

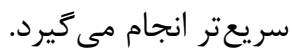
در اين يزوهش يك سيستم CAD خودكار بهمنظور

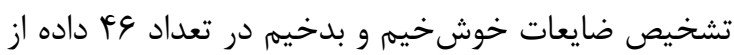

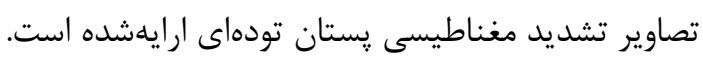
سيستم ييشنهادى در دوطبقه اصلى CADe و CADe

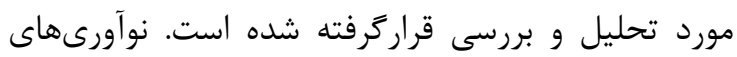

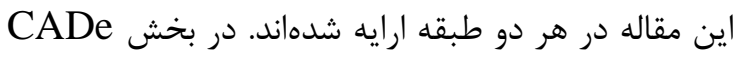
از يك الكوريتم پيشنههادى بلهنظور جداسازى ناحيه

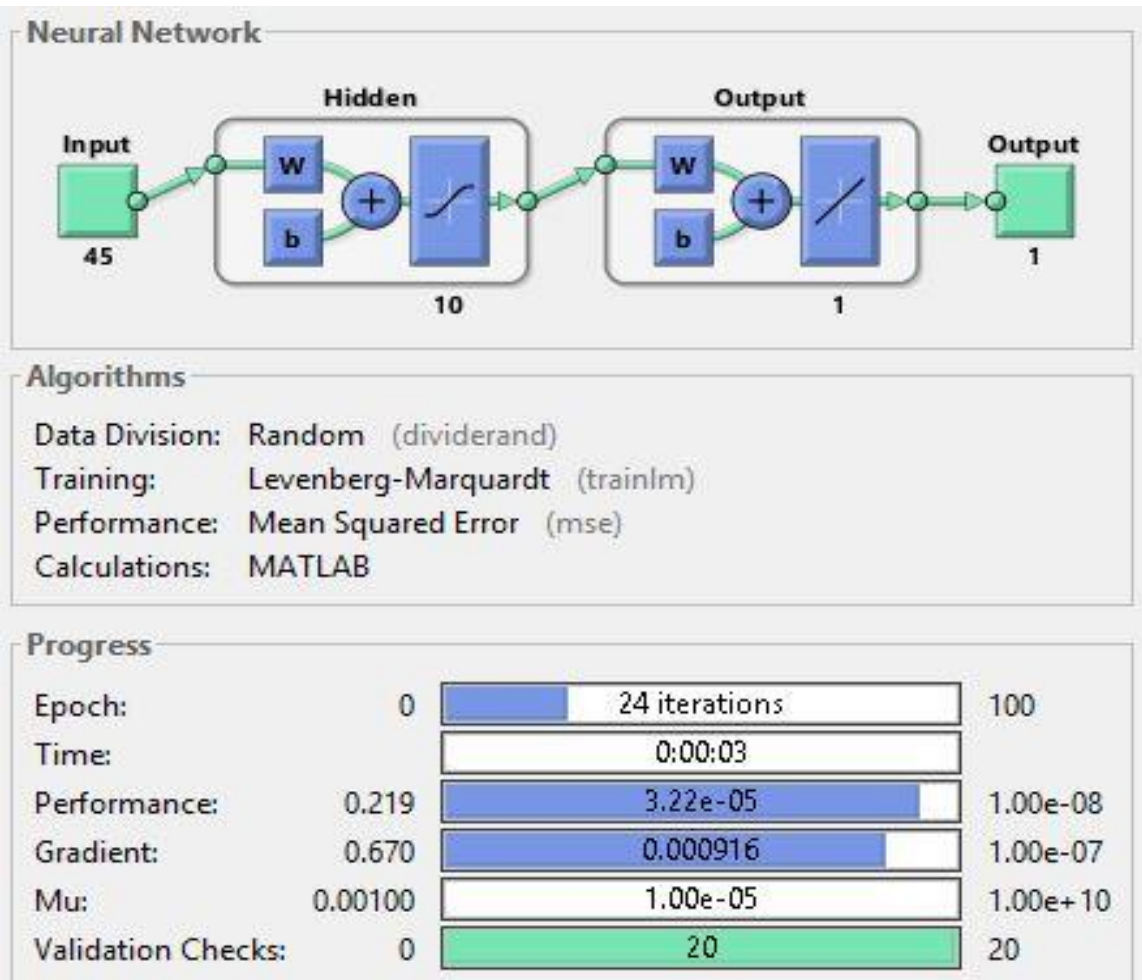

شكل 9: هارامترهاى ارزيابى و ساختار شبكه عصبى مصنوعى MLP استفاده شده در اين يزوهش با الكور يتم يادكيرى لونبرك ماركوارث

مقايسه مىشود. از جمله محدوديتهايى كه در طول نتيجهكيرى

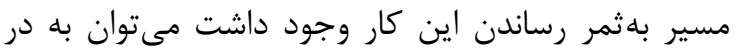

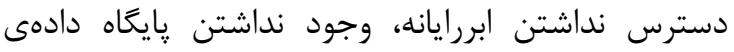

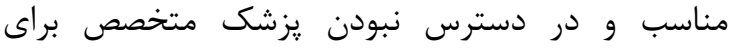

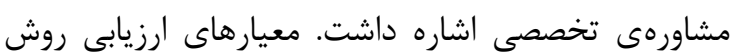
ييشنهادى در اين يزوهش ضريب جاكارد، ضريب شباهت در اين يزوهش تعداد لهr ضايعه بهمنظور ارزيابى روش

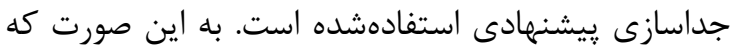

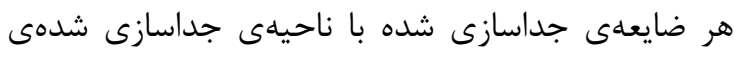
همان ضايعه كه توسط راديولوزيست انجام شده است 
استفاده شده است كه كارايى بسيار مناسبى را به نسبت ساير روشها از خود به نمايش گذاشته است. علاوهبراين در :زوهش حاضر ميزان خاصيت به نسبت يزوهشهاى

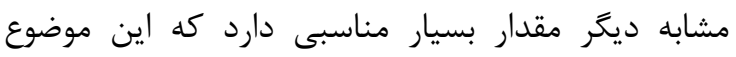

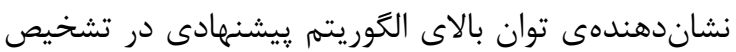
ضايعات بدخيم است. در مطالعه منتشر شده توسط بوري Rasti

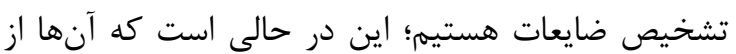

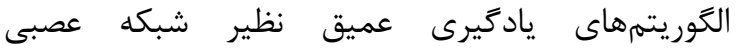

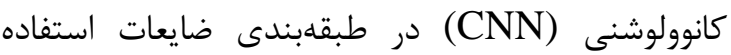
كردهاند كه خود داراى زيجزيدگى بسيار گستردهاى است.

\section{تقدير و تشكر}

يزوهش حاضر مستخرج از ياياننامه كارشناسى ارشد به

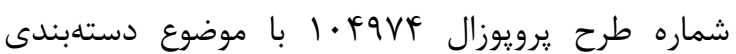
هوشمند ضايعات در تصاوير تشديد مغناطيسى يستان

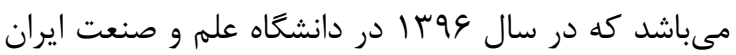
به تصويب رسيده است و در آن مراتب تقدير و تشكر از تمام كسانى كه در به سرانجام رساندن اين كار مارا يارى نمودند، اعلام شده است. در اينجا نيز صميمانه از خانم

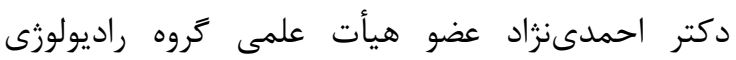
دانشعاه علوم يزشكى تهران به دليل همكارى در تهرئ پايڤاه داده و همجنين مركز تصويربردارى توسكا، نور و وليعصر به دليل همكارى در تكميل و تحليل يايعاه دادههاى موجود نهايت تشكر را دارم.

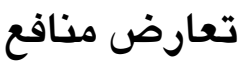

نويسند يزوهش حاضر وجود ندارد.

\section{References}

1. Siegel RL, Miller KD, Jemal A. Cancer statistics, 2017. CA: a cancer journal for clinicians. 2017; 67(1):7-30.

2. Siegel R, Ma J, Zou Z, Jemal A. Cancer statistics, 2014. CA: a cancer journal for clinicians. 2014; 64(1):9-29.

3. http://www.ircancer.ir.
دايس، نرخ مثبت و منفى كاذب مىباشند كه به ترتيب

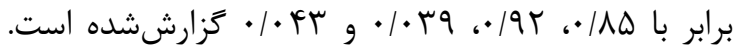
با توجه به نتايج كيفى نشان دادهشده در بخش قبل و

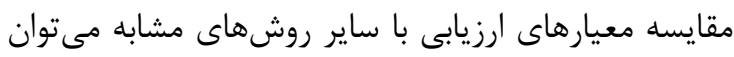
كارايى مناسب روش ريشنههادى را تاييد كرد.

قسمت بعدى درروش ييشنهادى CADx است كه تنها راه ارزيابى آن استفاده از يك دستهبندى كننده در در مراحل

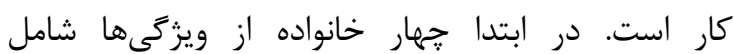

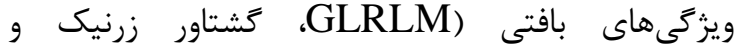
هاراليك)، ويزگى هاى فركانسى (كابور و تبديل موجى) ويززَى هاى ريختشناسى و سينتيك از هر تصوير استخراج مىشود. در اين ميان يك دسته ويزگى تركيبى به نام

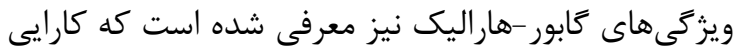
قابل قبولى از خود به نمايش كذاشته است. براى ارزيابى ويززى ها هر خانواده بهصورت جداگانه و براى حفظ كردن

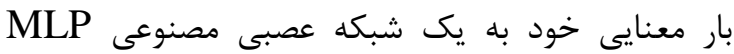

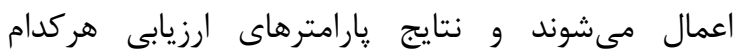
موردبررسى قرار مى گيرد. درنهايت در پايان اين مرحله

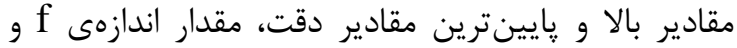
AUC

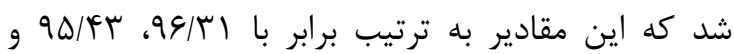

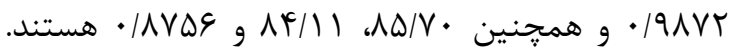

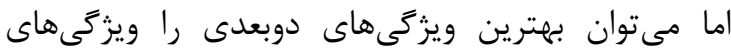
كابور-هاراليك (حقيقى) دانست زيرا كه مقادير يار امترهاى

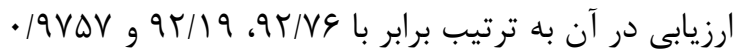
كَزارش نده است. مطابق با آنجه كه در جدول ^أ بيان شده است؛ نقطه قوت

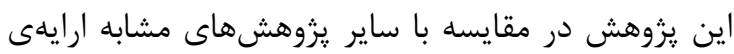
راهكارى براى طبقهبندى ضايعات در تصاوير دوبعدى با مرون بيشترين دقت است. اين در حالى است كه به منظور

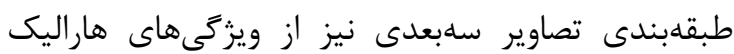

4. Rangayyan RM, Ayres FJ, Desautels JL. A review of computer-aided diagnosis of breast cancer: Toward the detection of subtle signs. Journal of the Franklin Institute. 2007; 344(3-4):312-48.

5. Liberman L. Percutaneous magnetic resonance imaging guided breast biopsy. Breast MRI: Springer; 2005: 297-315. 
6. https://www.who.int/cancer/publications/WR C_2014/en/http://www.behdasht.gov.ir/

7. Vos $\mathrm{T}$, Allen $\mathrm{C}$, Arora M, Barber RM, Bhutta ZA, Brown A, et al. Global, regional, and national incidence, prevalence, and years lived with disability for 310 diseases and injuries, 1990-2015: a systematic analysis for the Global Burden of Disease Study 2015. The Lancet. 2016; 388(10053):1545602.

8. Cormie P, Nowak AK, Chambers SK, Galvão DA, Newton RU. The potential role of exercise in neuro-oncology. Frontiers in oncology. 2015; 5(3):105-85.

9. Uematsu T, Kasami M, Yuen S. Neoadjuvant chemotherapy for breast cancer: correlation between the baseline MR imaging findings and responses to therapy. European radiology. 2010; 20(10):2315-22.

10. Giger ML, Chan HP, Boone J. Anniversary paper: History and status of $\mathrm{CAD}$ and quantitative image analysis: the role of Medical Physics and AAPM. Medical physics. 2008; 35(12):5799-820.

11. Biglia N, Bounous VE, Martincich L, Panuccio E, Liberale V, Ottino L, et al. Role of MRI (magnetic resonance imaging) versus conventional imaging for breast cancer presurgical staging in young women or with dense breast. European Journal of Surgical Oncology (EJSO). 2011; 37(3):199-204.

12. Fooladivanda A, Shokouhi SB, Ahmadinejad $\mathrm{N}$. Breast-region segmentation in MRI using chest region atlas and SVM. Turkish Journal of Electrical Engineering \& Computer Sciences. 2017; 25(6):4575-92.

13. Freer TW, Ulissey MJ. Screening mammography with computer-aided detection: prospective study of 12,860 patients in a community breast center. Radiology. 2001; 220(3):781-6.

14. Mousa DSA, Mello-Thoms C, Ryan EA, Lee WB, Pietrzyk MW, Reed WM, et al. Mammographic density and cancer detection: does digital imaging challenge our current understanding? Academic radiology. 2014; 21(11):1377-85.

15. Ertas G, Doran SJ, Leach MO. A computerized volumetric segmentation method applicable to multi-centre MRI data to support computer-aided breast tissue analysis, density assessment and lesion localization. Medical \& biological engineering \& computing. 2017; 55(1):5768.

16. Vovk U, Pernus F, Likar B. A review of methods for correction of intensity inhomogeneity in MRI. IEEE transactions on medical imaging. 2007; 26(3):405-21.

17. Szabó BK, Wiberg MK, Boné B, Aspelin P. Application of artificial neural networks to the analysis of dynamic MR imaging features of the breast. European radiology. 2004; 14(7):1217-25.

18. Anitha J, Peter JD. Mammogram segmentation using maximal cell strength updation in cellular automata. Medical \& biological engineering \& computing. 2015; 53(8):737-49.

19. Caselles V, Kimmel R, Sapiro G. Geodesic active contours. International journal of computer vision. 1997; 22(1):61-79.

20. Chaieb R, Bacha A, Kalti K, Lamine FB, editors. Image features extraction for masses classification in mammograms. Soft Computing and Pattern Recognition (SoCPaR), 2014 6th International Conference of; 2014: IEEE.

21. Chu J, Min H, Liu L, Lu W. A novel computer aided breast mass detection scheme based on morphological enhancement and SLIC superpixel segmentation. Medical physics. 2015; 42(7): 3859-69.

22. Abdel-Nasser M, Rashwan HA, Puig D, Moreno A. Analysis of tissue abnormality and breast density in mammographic images using a uniform local directional pattern. Expert Systems with Applications. 2015; 42(24): 9499-511.

23. ping Tian D. A review on image feature extraction and representation techniques. International Journal of Multimedia and Ubiquitous Engineering. 2013; 8(4):385-96.

24. Fooladivanda A, Shokouhi SB, Ahmadinejad N. Localized-atlas-based segmentation of breast MRI in a decision-making framework. Australasian physical \& engineering sciences in medicine. 2017;40(1):69-84.

25. Li C, Huang R, Ding Z, Gatenby J, Metaxas DN, Gore JC. A level set method for image segmentation in the presence of intensity inhomogeneities with application to MRI. IEEE Transactions on Image Processing. 2011; 20(7):2007.

26. Pashoutan S, Shokouhi SB, Pashoutan M, editors. Automatic Breast Tumor Classification Using a Level Set Method and Feature Extraction in Mammography. 2017 24th National and 2nd International Iranian Conference on Biomedical Engineering (ICBME); 2017: IEEE.

27. Frangi AF, Niessen WJ, Vincken KL, Viergever MA, editors. Multiscale vessel 
enhancement filtering. International Conference on Medical Image Computing and Computer-Assisted Intervention; 1998.

28. Miller KD, Siegel RL, Lin CC, Mariotto AB, Kramer JL, Rowland JH, et al. Cancer treatment and survivorship statistics, 2016. CA: a cancer journal for clinicians. 2016; 66(4):271-89.

29. Agner SC, Soman S, Libfeld E, McDonald M, Thomas K, Englander S, et al. Textural kinetics: a novel dynamic contrast-enhanced (DCE)-MRI feature for breast lesion classification. Journal of digital imaging. 2011; 24(3):446-63.

30. Maglogiannis I, Zafiropoulos E, Anagnostopoulos I. An intelligent system for automated breast cancer diagnosis and prognosis using SVM based classifiers. Applied intelligence. 2009; 30(1):24-36.

31. McLaren CE, Chen W-P, Nie K, Su M-Y. Prediction of malignant breast lesions from MRI features: a comparison of artificial neural network and logistic regression techniques. Academic radiology. 2009; 16(7): 842-51.

32. Newell D, Nie K, Chen J-H, Hsu C-C, Hon JY, Nalcioglu O, et al. Selection of diagnostic features on breast MRI to differentiate between malignant and benign lesions using computer-aided diagnosis: differences in lesions presenting as mass and non-mass-like enhancement. European radiology. 2010; 20(4):771-81.

33. Fusco R, Sansone M, Filice S, Carone G, Amato DM, Sansone C, et al. Pattern recognition approaches for breast cancer DCE-MRI classification: a systematic review. Journal of medical and biological engineering. 2016; 36(4):449-59.

34. ping Tian D. A review on image feature extraction and representation techniques. International Journal of Multimedia and Ubiquitous Engineering. 2013; 8(4):385-96.

35. Mudigonda NR, Rangayyan R, Desautels JL. Gradient and texture analysis for the classification of mammographic masses. IEEE transactions on medical imaging. 2000; 19(10):1032-43.

36. Haralick RM, Shanmugam K. Textural features for image classification. IEEE Transactions on systems, man, and cybernetics. 1973; (6):610-21.

37. Galloway MM. Texture analysis using grey level run lengths. NASA STI/Recon Technical Report N. 1974;75.

38. Quinlan JR. C4. 5: programs for machine learning: Elsevier; 2014.
39. Kittler J. Feature selection and extraction. Handbook of pattern recognition and image processing. 1986.

40. Ferrari RJ, Rangayyan RM, Desautels JL, Frère AF. Analysis of asymmetry in mammograms via directional filtering with Gabor wavelets. IEEE Transactions on Medical Imaging. 2001; 20(9):953-64.

41. Manjunath BS, Ma W-Y. Texture features for browsing and retrieval of image data. IEEE Transactions on pattern analysis and machine intelligence. 1996; 18(8):837-42.

42. Chang Y-C, Huang Y-H, Huang C-S, Chen J-H, Chang R-F. Computerized breast lesions detection using kinetic and morphologic analysis for dynamic contrast-enhanced MRI. Magnetic resonance imaging. 2014; 32(5):514-22.

43. Gubern-Mérida A, Kallenberg M, Marti R, Karssemeijer N, editors. Fully automatic fibroglandular tissue segmentation in breast MRI: atlas-based approach. MICCAI Workshop: Breast Image Analysis; 2011.

44. Parinaz E. Computer-Aided Diagnosis system for Segmentation and classification of tumor in breast MRI [dissertation]. [Iran]: Iran university of science and technology; 2016.

45. A bdolmaleki P, Buadu LD, Naderimansh $H$. Feature extraction and classification of breast cancer on dynamic magnetic resonance imaging using artificial neural network. Cancer letters. 2001; 171(2):183-91.

46. Newell D, Nie K, Chen J-H, Hsu C-C, Hon JY, Nalcioglu $\mathrm{O}$, et al. Selection of diagnostic features on breast MRI to differentiate between malignant and benign lesionFs using computer-aided diagnosis: differences in lesions presenting as mass and non-mass-like enhancement. European radiology. 2010; 20(4):771-81.

47. Huang Y-H, Chang Y-C, Huang C-S, Wu TJ, Chen J-H, Chang R-F. Computer-aided diagnosis of mass-like lesion in breast MRI: differential analysis of the 3-D morphology between benign and malignant tumors. Computer methods and programs in biomedicine. 2013;112(3):508-17.

48. Lucht RE, Knopp MV, Brix G. Classification of signal-time curves from dynamic MR mammography by neural networks. Magnetic resonance imaging. 2001; 19(1): 51-7.

49. Honda E, Nakayama R, Koyama H, Yamashita A. Computer-aided diagnosis scheme for distinguishing between benign and malignant masses in breast DCE-MRI. 
Journal of digital imaging. 2016; 29(3):38893.

50. Rasti R, Teshnehlab M, Phung SL. Breast cancer diagnosis in DCE-MRI using mixture ensemble of convolutional neural networks. Pattern Recognition. 2017; 72(1):381-90. 